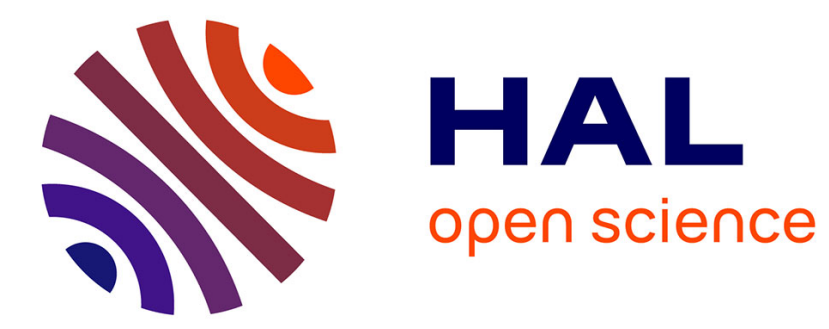

\title{
Retired at last? Past working conditions and the role of retirement in health status
}

Thomas Barnay, Éric Defebvre

\section{To cite this version:}

Thomas Barnay, Éric Defebvre. Retired at last? Past working conditions and the role of retirement in health status. 2021. hal-03238458

\section{HAL Id: hal-03238458 \\ https://hal.science/hal-03238458}

Preprint submitted on 27 May 2021

HAL is a multi-disciplinary open access archive for the deposit and dissemination of scientific research documents, whether they are published or not. The documents may come from teaching and research institutions in France or abroad, or from public or private research centers.
L'archive ouverte pluridisciplinaire HAL, est destinée au dépôt et à la diffusion de documents scientifiques de niveau recherche, publiés ou non, émanant des établissements d'enseignement et de recherche français ou étrangers, des laboratoires publics ou privés. 

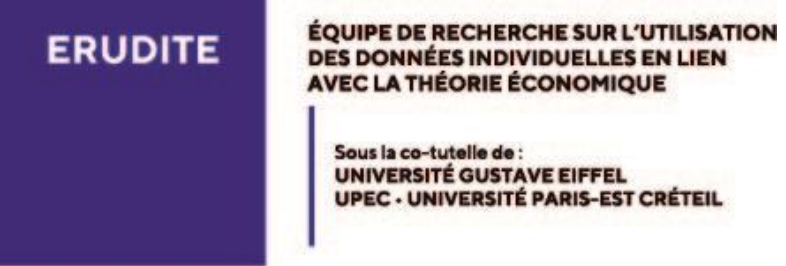

\section{Series of ERUDITE Working Papers}

$N^{\circ} 11-2020$

\section{Title}

Retired at last?

Past working conditions and the role of retirement in health status

\section{Authors}

Thomas Barnay, Éric Defebvre 


\title{
RETIRED AT LAST? \\ PAST WORKING CONDITIONS AND THE ROLE OF RETIREMENT IN HEALTH STATUS \\ Thomas Barnay and Éric Defebvre
}

\begin{abstract}
This paper assesses the role played by retirement in health status by considering past working conditions. Using data from the French Health and Professional Path survey, we address the endogeneity biases resulting from retirement by setting up an instrumental variable method that relies on retirement age thresholds as sources of exogeneity. A matching method tackles the endogenous selection through classification into certain types and amplitudes of exposure to work strains. We find that retirement per se has positive effects on the general and mental health of less exposed individuals while yielding considerably greater improvements overall for workers retiring from highly demanding careers. The effect of retirement for lowskilled men exposed to average physical strains on their probability to declare poor selfassessed health amounts to $-21.7 p p$. These results advocate the need for preventive measures aimed towards exposures to work strains and/or differentiated retirement schemes according to the nature and intensity of a pensioner's entire work life.
\end{abstract}

Prof. Thomas BARNAY, Ph.D.

Thomas Barnay is a Professor of Economics at UPEC

ERUDITE, Université Paris-Est Créteil (UPEC)

61, avenue du Général de Gaulle

94000 Créteil

France

Phone: 00-33-1-41-78-46-50

Corresponding author: barnay@u-pec.fr

Éric DEFEBVRE, Ph.D., Associate Professor

Eric Defebvre is an Assistant Professor of Economics at Paris 1 Panthéon-Sorbonne University Centre d'Économie de la Sorbonne (CES), Paris 1 Panthéon-Sorbonne University and Tepp FR n`3435-CNRS, eric.defebvre@univ-parisl.fr

JEL: I14, J26, C35, C36

Keywords: Retirement; Working conditions; Physical health; Mental health; Instrumental variables; Matching method; France

Funding: This research benefited from the support of the Demographic Transitions, Economic Transitions Chair (Paris, France) under the aegis of the Risk Foundation.

Conflict of interest: The authors declare that they have no conflict of interest. 


\section{INTRODUCTION}

The reforms to the French pay-as-you-go pension scheme that were put in place in 1993 relied on increases in the required length of contribution and on postponing the legal retirement age to 62 years of age - which may even be extended to 64 years in a future pension reform discussed in 2019. One of the most controversial remaining points concerns the role of work drudgery in health status at later ages, an issue that is increasingly relevant because working longer may result in potentially greater exposure to detrimental working conditions. Thus, older workers subject to high levels of exposure may be unable to reach this legal retirement age. Furthermore, deferring retirement age could worsen adverse health for the most exposed workers. Thus, the nature of past working conditions is particularly pertinent to understanding the role of retirement in individuals' well-being at older ages.

From a theoretical point of view, it is no trivial task to study the effects of retirement on health status based on past exposure to detrimental working conditions. On the one hand, the role played by retirement is unclear due to its incurring competitive effects-notably by freeing individuals from job strain and thus improving health — while it may also induce feelings of lost social utility, thus leading to a decline in cognitive functions and reduced self-esteem (Rohwedder and Willis, 2010). Combining work and a pension is very rare in France, and the transition to retirement persists mostly as the irreversible shock of an absorbing state that may reinforce these positive or negative effects. Endogeneity biases are also very common in statistical methodology, for example in the form of reverse causality, as health status constitutes one of the most important non-monetary drivers in the trade-off between work and leisure in older workers (Barnay, 2016; Lindeboom, 2006). Additionally, many unobservable individual characteristics may also explain both retirement behaviours and health status. On the other hand, studying such effects is not trivial because workers are endogenously selected into certain jobs that incur specific types of work strains and thereby erode the classical relationship between working conditions and health consequences (Cottini and Lucifora, 2013).

The aim of this paper is thus twofold. First, we tackle the endogeneity biases resulting from both retirement and working conditions by using a mixed econometric strategy that relies on instrumental variables and exact matching. Second, we test whether the effect of retirement on health differs according to the nature and amplitude of past exposure to detrimental working conditions. With the aid of the French Santé et Itinéraire Professionnel (Health and Professional Career [SIP]) survey dataset, we observe yearly work strains from the beginning of one's career 
to the date of the survey to study the cumulative effects of exposures. To our knowledge, this is the only paper that comprehensively considers the whole career in order to provide insights on the role of arduous careers in the effects of retirement on health status.

The paper is organized as follows. Section 1 is dedicated to an empirical literature review on the relationships between retirement and health status. Sections 2 and 3 then describe the dataset. Section 4 presents the empirical strategy and Section 5 the results. Finally, Sections 6 and 7 conclude.

\section{Background and literature}

1.1. "Retirement blues" (Heller-Sahlgren, 2017) and "Unhealthy Retirement" (Mazzonna and Peracchi, 2017)

At first, retirement may incur the loss of one's social role (Kim and Moen, 2002) and a reduction in social capital, therefore leading to a deterioration in health that is aggravated indirectly by an average reduction in living standards. The so-called unengaged lifestyle hypothesis means that the work environment is more cognitively stimulating than the leisure environment. This adverse effect complies with the theoretical framework proposed by Grossman (1972) to the extent that retirees reduce their investment in cognitive abilities after retiring. In this respect, Rohwedder and Willis (2010) show that early retirement has a significant adverse impact on cognitive abilities. Other studies also reach similar conclusions (Dave et al., 2008; Mazzonna and Peracchi, 2009; Behncke, 2012; Bonsang et al., 2012).

A set of recent studies generalizes this detrimental effect of retirement on health. Behncke (2012) used the English Longitudinal Study of Ageing to find that retirement increases the occurrence of chronic health conditions. Similarly, Celidoni et al. (2017) used Survey of Health, Ageing and Retirement in Europe (SHARE) data to evaluate the causal impact of retirement on recall memory tests based on the eligibility ages for early and legal retirement in several European countries, by which they found retirement has a long-term negative effect on cognition for individuals who retire at the statutory eligibility age. Taking advantage of SHARE's panel dimension, Mazzonna and Peracchi (2017) used a two-stage least squares first difference (2SLS-FD) estimator to show that retirement is on average negative for both mental and physical health (depression and mobility limitation) as well as for cognitive abilities (memory and fluency). Heller-Sahlgren (2017) took a fixed-effect instrumental variable approach while also using SHARE to investigate the short- and long-term effects of retirement 
on mental health (Euro-D scale) in ten European countries, for which they found a negative long-term effect.

\subsection{A well-deserved retirement?}

Retirement can also free individuals from job strain situations and improve their health conditions over the short term. This virtuous circle is sustainable if individuals are able to invest in their health (income effect). Many international empirical studies show that retirement is beneficial to health status (Blake and Garrouste, 2019; Charles, 2002; Coe and Zamarro, 2011; Grip et al., 2012; Insler, 2014; Neuman, 2008). Coe and Zamarro (2011) conclude that retirement decreases the likelihood of reporting poor perceived health (35\%) after controlling for reverse causality. However, this effect is not borne out with both depression indicators (the Euro-D scale and the feeling of being depressed). In the U.K., Bound and Waidmann (2007) found a positive but transitory health effect of retirement in men only. Based on German data, Eibich (2015) finds that retirement improves general and mental health status by performing a Regression Discontinuity Design in order to explore financial incentives in the German pension scheme. Using three different datasets, Shai (2018) uses a 2004 pension reform as a source of exogeneity in order to study the influence of retirement on health. He underlines that being in employment at older ages is related to poor general health or, in other words, that retirement is beneficial. In France, Blake and Garrouste (2019) point out a negative effect on health from the 1993 pension scheme reform that increased the duration of the contribution period, although they focused exclusively on less-educated individuals. Finally, by performing a difference-indifferences method on French data, Messe and Wolff (2019) show that the probability of selfreporting poor health is significantly lower for retirees in comparison to individuals remaining in employment.

\subsection{Heterogeneous effects related to working conditions}

This ambiguous effect of retirement might be related to time span and ultimately point towards the role played by past exposures to working conditions. Thus, because on the one hand Mazzonna and Peracchi (2017) found a positive short-term effect in a subsample characterized by more physically demanding jobs and, on the other, individuals employed in low-skill jobs are overrepresented in early retirees, we can assume that the positive effect of retirement on health is often related to early retirement. Unlike late retirees, people who retire as soon as possible benefit from positive effects on their cognitive abilities (Celidoni et al., 2017). As a consequence, the negative effect of retirement may not be instantaneous (Bonsang et al., 2012; 
Mazzonna and Peracchi, 2012; Heller-Sahlgren, 2017), implying that the adverse effect may appear in the long run. Yet, the effect of working conditions on health after retirement remains mostly unclear, notably due to data limitations because working condition indicators are not always available (specifically those relying on administrative data); and, when they are, they almost always cover only the short term (for the last job before retiring). This is a matter of concern because exposures to detrimental working conditions can be simultaneous and are notorious for having cumulative effects on health status (de Jonge et al., 2000; Michie and Williams, 2003; Fletcher et al., 2011; Defebvre, 2018). In particular, the rather counterintuitive findings of Coe and Lindeboom (2008) and more recently Gorry et al. (2018) show that workers exposed to the most arduous jobs (i.e., blue-collar workers) experience the smallest improvements in health status after retirement when compared to white-collar workers and more educated individuals. In contrast, Coe et al. (2012) find only a positive effect of retirement on blue-collar workers' cognitive functioning. These results have a number of potential explanations, from the weight of the selected health indicator to the necessity of handling endogeneity biases resulting from occupational variables. Therefore, the data is very demanding when appropriately evaluating the impact of these indicators and variables on retirement's role in health status, especially among older workers.

\subsection{Biases}

Determining the effects of retirement on retirees' health status is a challenging task. Even if health declines with age, estimates are subject to endogeneity biases, of which two major sources can be identified. The first is the existing two-way relationship between retirement and health. In particular, the decision to retire depends on prior health status, leading to a healthrelated selection bias. The second source is related to the unobserved factors influencing not only health status but also retirement. To the extent that individuals have different characteristics (subjective life expectancy, risk aversion preferences, and disutility of work), the estimates are then at risk of being biased. These endogeneity biases have long been discussed in the related literature (Coe and Zamarro, 2011).

The exposure to detrimental working conditions also undergoes endogeneity biases, making the joint study of retirement and past exposures particularly difficult. The choice of a job is indeed unlikely to be a random experience (Cottini and Lucifora, 2013). Healthier individuals may tend to prefer (self-selection) more demanding jobs or be preferred (discrimination) for them (Barnay et al. 2015). Second, it is also likely that workers with lesser health capital may have fewer opportunities in the labour market and thus be restricted to the toughest jobs. Due to a 
lack of panel data that includes comprehensive information on both work and health status over longer periods, relatively few papers have actually succeeded in handling these biases. Among those that have, they control for baseline health status and random effects (Fletcher et al., 2011), use instrumental variables (Cottini and Lucifora, 2013), or rely on matching methods (Defebvre, 2018).

\section{Data}

\subsection{The SIP dataset}

The Santé et Itinéraire Professionnel survey (SIP) provides particularly detailed individual descriptions. Aside from the usual socioeconomic variables (age, sex, activity sector, professional category, educational level, and marital status), it also contains specific items concerning physical and mental health. Designed jointly by the French Ministries in charge of Healthcare and Labour, the survey was conducted in two waves (2006 and 2010) on the same sample of people aged 20-74 years living in private households in mainland France. Two questionnaires were made available. The first was administered by an interviewer and accurately compiled individual and job characteristics as well as the respondent's current health status. It also reconstructed individual careers and life events with a biographical life grid covering childhood, education, health, career changes, working conditions, and significant life events. The second was a self-administered questionnaire targeting risky health behaviours (weight, tobacco use, and alcohol consumption). A total of 13,648 people were interviewed in 2006 , and 11,016 of them again in 2010. We use the biographical dimension of the 2006 survey for a yearly reconstruction of workers' careers and are therefore able to know each individual's employment status and working conditions every year from their childhood to the date of the first survey (2006). As far as work strains are concerned, the survey provides information about exposure using ten indicators: night work, repetitive work, physical load, exposure to toxic materials, full skill usage, work under pressure, tensions with the public, reward, conciliation between work and family life, and relationships with colleagues. The intensity of exposure to these work strains is also known. Appendix 1 provides more information on representativity, response rates, and attrition between 2006 and 2010.

Our sample retains only interviewees present in both the 2006 and 2010 waves, i.e., 11,016 individuals. In order to avoid overly heterogeneous samples and because we study matters related to retirement, we selected individuals aged 45-74 in 2010, thus allowing us to benefit from all the necessary information on pension and health status characteristics. This allows us 
to make the best possible use of counterfactuals and of our sample of retirees (of whom some retired particularly early and others rather late [see Figure 1: Cumulative proportion of retirees in the sample according to age

]) while still limiting a good portion of the unnecessary heterogeneity. Thus, we ultimately study a sample of 6,472 individuals, of whom 2,748 are retired.

\subsection{Variables}

\subsubsection{Variables of interest}

We use three general health indicators: self-assessed health (SAH) status (binary: very good and good versus fair, bad, and very bad); the presence of chronic illnesses (binary); and limitations in daily activities (binary). We also use two mental health indicators: generalised anxiety disorders (GAD, binary) and major depressive episodes (MDE, binary) (Appendix 2). Regarding retirement status, we use a question that specified current occupation status in 2010 and then build a dummy variable equal to 1 if the individual has reported being retired or preretired at this date, and 0 otherwise. About half of the sample had not yet retired in 2010. No specific selection of the sample is made apart from retaining individuals aged 45-74 in 2010. Thus, individuals retired in 2010 may have been so for some time or they could have been in other situations (at work, unemployed, or inactive). Further details are provided in Appendix 3.

\subsubsection{Working conditions}

Based on retrospective data collected in 2006, we reconstructed the yearly professional paths (including working conditions) of individuals from the end of their initial studies to the end of their careers, then used ten individual annual indicators to assess their exposure to detrimental work strains, which the individuals had declared whether they "always", "often", "sometimes" or "never" experienced during the period. The physical workload is represented by night work, repetitive work, physical load, and exposure to toxic materials. Psychosocial risk factors include full skill usage, working under pressure, tensions with the public, reward, conciliation between work and family life, and relationships with colleagues.

Based on these ten base working conditions variables, we built two global indicators, each one for the physical and psychosocial dimensions. An individual is considered exposed for any given year if he/she "always" or "often" declared facing these strains, and each physical and psychosocial indicator therefore simply represents the cumulative number of years of exposure experienced by an individual during his/her career in 2010 . 
We also need binary indicators to characterize exposure to detrimental working conditions. Thus, we built two overexposure variables that each take the value 1 if an individual faced physical or psychosocial strains for more than the sample's average number of exposure years (including those who were never exposed), and 0 otherwise.

We assume that individuals having faced such strains at work should be even more relieved by retirement, thereby inducing heterogeneity in retirement's effect on health status.

\subsubsection{Control variables}

We control all our results by gender, age, age squared, educational level (no education, primary/secondary, equivalent to bachelor's degree, and post graduate), having had at least one child and activity sector (public sector, private sector, or self-employed when applicable, i.e., when non-retired). We include indicators for having spent the main part (more than 50\%) of the career in long-term jobs of more than 5 years and, finally, an indicator for career stability (i.e., between 0 and 3 transitions during the whole career between four different states: employment spans lasting more than 5 years, employment spans lasting less than a year, unemployment spans of more than a year, and inactivity spans of more than a year).

\subsubsection{Matching variables}

We also consider the period before labour market entry by observing health status (heavy health problems and handicaps) within that period, as well as important events during childhood. These were aggregated into three dummy variables. One dummy variable represents issues related to relatives, namely major health problems of relatives, death of a relative, and separation from one or more parents. Another represents violence suffered from relatives, at school, or in the neighbourhood. The third dummy variable represents childhood by aggregating family conflicts and harsh living conditions. Finally, we also use year of entry into the labour market.

\section{Descriptive statistics}

$42 \%$ of the sample is retired in 2010, among whom the mean duration of retirement is around 7 years. Retirees systematically self-report a worse general health condition but better mental health status than non-retirees, despite the 13-year gap in age between the two populations (Table 1). Yet, $41 \%$ of the retired population declare poor SAH against 33\% in the non-retired population; 53\% a chronic disease (against 38\%); and 28\% limitations in their daily activities (against 22\%). The retired population suffers less from anxiety disorders (5\%) and depressive 
episodes (6\%) than the control group (8\% each for the GAD and MDE mental health indicators). Exposure to harsh physical and psychosocial working conditions is much higher among retirees than among non-retirees, as it is likely that the last years of professional life are marked by greater exposures.

Table 1: General descriptive statistics

\begin{tabular}{|c|c|c|c|c|c|c|c|}
\hline \multirow{2}{*}{ Variable } & \multirow{2}{*}{ Mean } & \multirow{2}{*}{ Std. error } & \multirow{2}{*}{ Min. } & \multirow{2}{*}{ Max. } & \multicolumn{3}{|c|}{ Mean by retirement status } \\
\hline & & & & & Retired & Non-retired & Difference \\
\hline \multicolumn{8}{|l|}{ Retirement \& exposure } \\
\hline Retired & .42 & .49 & 0 & 1 & - & - & - \\
\hline Physical exposure & 7.94 & 11.79 & 0 & 44 & 10.92 & 5.75 & $-5.17 * * *$ \\
\hline Psychosocial exposure & 6.26 & 9.78 & 0 & 40 & 7.80 & 5.13 & $-2.67 * * *$ \\
\hline Retired $\times$ Physical exp & 4.64 & 10.98 & 0 & 44 & - & - & - \\
\hline Retired × Psycho. exp. & 3.31 & 8.67 & 0 & 40 & - & 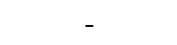 & 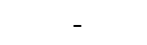 \\
\hline Age above 55 & .65 & .48 & 0 & 1 & .99 & .39 & $-.60^{* * * *}$ \\
\hline Age above 60 & .45 & .50 & 0 & 1 & .93 & .10 & $-.83 * * *$ \\
\hline Age above 65 & .25 & .43 & 0 & 1 & .57 & .02 & $-.55 * * *$ \\
\hline Retirement duration & 6.92 & 5.25 & 0 & 51 & - & - & - \\
\hline \multicolumn{8}{|l|}{ Health status } \\
\hline Poor SAH & .37 & .48 & 0 & 1 & .41 & .33 & $-.08 * * *$ \\
\hline Chronic disease & .44 & .50 & 0 & 1 & .53 & .38 & $-.15^{* * * *}$ \\
\hline Activity limitation & .25 & .43 & 0 & 1 & .28 & .22 & $-.07 * * *$ \\
\hline Anxiety disorder & .07 & .25 & 0 & 1 & .05 & .08 & $.03 * * *$ \\
\hline Depressive episode & .07 & .26 & 0 & 1 & .06 & .08 & $.02 * * *$ \\
\hline \multicolumn{8}{|l|}{ Demographics } \\
\hline Male & .46 & .50 & 0 & 1 & .51 & .43 & $-.07 * * *$ \\
\hline Age & 58.40 & 8.09 & 45 & 74 & 65.72 & 53.00 & $-12.71 * * *$ \\
\hline Children & .90 & .30 & 0 & 1 & .91 & .90 & $-.01 * *$ \\
\hline \multicolumn{8}{|l|}{ Education } \\
\hline No education & .08 & .28 & 0 & 1 & .09 & .08 & $-.02 * *$ \\
\hline Primary/secondary & .57 & .49 & 0 & 1 & .64 & .53 & $-.11 * * *$ \\
\hline Bachelor equivalent & .14 & .35 & 0 & 1 & .11 & .17 & $.05^{* * *}$ \\
\hline Post graduate & .18 & .39 & 0 & 1 & .14 & .21 & $.07 * * *$ \\
\hline \multicolumn{8}{|l|}{ Employment } \\
\hline Public sector & .16 & .37 & 0 & 1 & .08 & .22 & $.14 * * *$ \\
\hline Private sector & .35 & .48 & 0 & 1 & .15 & .50 & $.35 * * *$ \\
\hline Self-employed & .06 & .24 & 0 & 1 & .03 & .09 & $.07 * * *$ \\
\hline Long-term jobs & .78 & .41 & 0 & 1 & .82 & .75 & $-.07 * * *$ \\
\hline Stable career & .55 & .50 & 0 & 1 & .49 & .60 & $.10^{* * * *}$ \\
\hline \multicolumn{8}{|l|}{ Matching variables } \\
\hline Physically overexposed & .37 & .48 & 0 & 1 & .42 & .34 & $-.08 * * *$ \\
\hline Psychosocially overexposed & .37 & .48 & 0 & 1 & .38 & .36 & $-.02 *$ \\
\hline Entry year on labour market & 1969.40 & 9.31 & 1947 & 1996 & 1961.4 & 1975.3 & $13.99 * * *$ \\
\hline \multicolumn{8}{|l|}{ Childhood events } \\
\hline - Problems in relatives & .38 & .48 & 0 & 1 & .39 & .36 & $-.03 * *$ \\
\hline - Facing violence & .07 & .26 & 0 & 1 & .07 & .08 & .01 \\
\hline - Health problems & .09 & .28 & 0 & 1 & .09 & .08 & -.00 \\
\hline - Poor material conditions & .23 & .42 & 0 & 1 & .24 & .22 & $-.02 * *$ \\
\hline $\mathbf{N}$ & & & & 6472 & & & \\
\hline
\end{tabular}

Note. $* * *$ Significant at the $1 \%$ level. ** Significant at $5 \%$. Significant at $10 \%$.

Reading guide: The total sample has been exposed to physical strains for an average of 7.94 years. This average is 10.92 years in the retired population, while it amounts to only 5.75 years in the not-yet-retired population.

Field: Santé et Itinéraire Professionnel survey, individuals aged 45-74 in 2010. 
Three retirement ages seem to emerge as the most common in the sample: ages 55, 60, and 65 . Age 60 is by far the most common (Figure 1: Cumulative proportion of retirees in the sample according to age

) and corresponds to the legal age of retirement for the studied period. Thus, when the proportion of pensioners represents only about $43 \%$ of the sample's total at age 59 , it amounts to more than $78 \%$ just a year later. Smaller discontinuities in the cumulative probability of being retired are also seen between ages $54(7 \%)$ and $55(15 \%)$ as well as between ages 64 (92\%) and $65(99 \%)$.

Figure 1: Cumulative proportion of retirees in the sample according to age

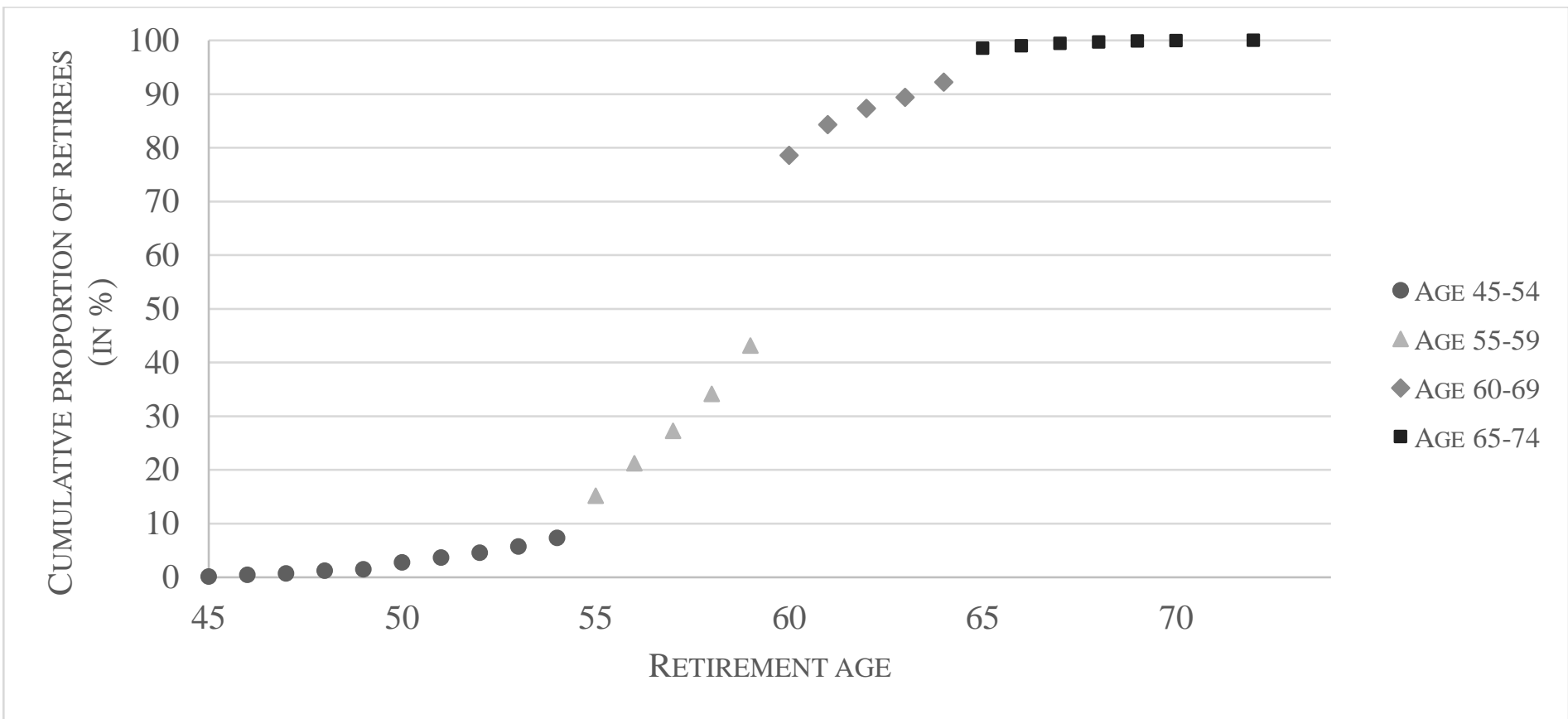

Field: Santé et Itinéraire Professionnel survey, individuals aged 45-74 in 2010.

\section{Empirical strategy}

4.1. Instrumental variables approach

\subsubsection{Idea}

Our identification strategy relies on the use of legal norms, which are therefore regarded as sources of exogeneity in the relationship (Coe and Zamarro, 2011; Mazzonna and Peracchi, 2012, 2017). To the extent that specific retirement ages exist in our sample (55 for early retirement [ERA hereafter]; 60 for the most common [NRA]; and 65 for later retirement 
[LRA]), we use these indicators as instrumental variables for the retirement process. However, reaching a specific age is not the only predictor of retirement status.

\subsubsection{Hypotheses}

Instrumental variable methods are based on two assumptions that are widely discussed in the literature. The relevance assumption considers the instruments to be correlated with the endogenous variable. In our case, the three instruments induce heavy financial incentives and/or the use of retirement schemes focused on specific populations. They appear intrinsically relevant to explaining one's decision to retire (see Figure 1: Cumulative proportion of retirees in the sample according to age

). The validity assumption states that the instruments are not correlated with the error term and thus reaching a certain age shall not induce discontinuities in health status. While it is obvious that age as a whole plays a significant role in health, it appears more doubtful that reaching a specific given age (for instance, age 60) induces a significant decline (or improvement) in health when compared to immediately prior health status (for example, at age 59) (Eibich 2015). To the extent that the legal age of retirement is determined by the government at a national level, this hypothesis is not particularly worrying - especially considering that age is controlled for in the regressions. Appendix 4 presents the proportions of the total sample declaring health conditions for each year of age. No real discontinuity can be seen at the threshold ages of 55, 60 , and 65, despite the sample sizes sometimes being rather low and the absence of any control variables. Furthermore, the hypothesis is confirmed later by running specific tests during the estimations.

\subsection{Estimation}

\subsubsection{Naïve approach}

The classical issue that such studies face concerns individuals being observed either as retired (treated) or not (control), and not simultaneously in both states. Let $Y_{i 1}$ and $Y_{i 0}$ denote, respectively, the health outcomes for the treated $\left(T_{i}=1\right)$ and control $\left(T_{i}=0\right)$ groups. As such, $Y_{i 1}$ is not observed when $T_{i}=0$ thus making the evaluation of the effect of retirement on health $\left(Y_{i 1}-Y_{i 0}\right)$ difficult.

In the first step, we explain health status in $2010\left(Y_{2010, k, i}\right.$, for health indicator $k$ and individual $i)$ by retirement $\left(R_{2010, i}\right)$ and the number of years exposed to detrimental working conditions during the whole career $\left(\operatorname{Expo}_{b i o, l, i}\right.$ for exposure type $l$ and individual $\left.i\right)$. We control the model 
for a vector of other explanatory variables observed in $2010\left(C_{2010, i}^{\prime}\right)$ and a vector of variables from the individual biography of the SIP survey $\left(C_{b i o, i}^{\prime}\right)$. Equation (1) is estimated by ordinary least squares (linear probability models) with heteroscedasticity-robust standard errors:

$$
Y_{2010, k, i}=\beta_{0}+\beta_{1} R_{2010, i}+\beta_{2} \operatorname{Expo}_{b i o, l, i}+\beta_{3} R_{2010, i} \times \operatorname{Expo}_{b i o, l, i}+\beta_{4} C_{2010, i}^{\prime}+\beta_{5} C_{b i o, i}^{\prime}+\varepsilon_{i}
$$

We introduce an interaction term $\left(R_{2010, i} \times E^{2 x p o_{b i o, l, i}}\right)$ between retirement and exposures to working conditions. The aim of this variable is to indicate whether the effect of retirement on health status varies depending on the level of exposure to the drudgery of work, which is assessed for the whole career.

\subsubsection{Endogeneity of retirement}

In order to tackle the related endogeneity biases, we rely on age thresholds to identify the relationship between health and retirement. We thus estimate the average treatment effect at these thresholds (denoted $\overline{A g e}): \mathbb{E}\left(Y_{i 1}-Y_{i 0} \mid A g e_{i}=\overline{A g e}\right.$ ), as described in Coe and Zamarro (2011) and Hahn et al. (2001). Formally, even if achieving or exceeding a certain age $\overline{A g e}$ does not fully determine the retirement status, it significantly influences the probability of being

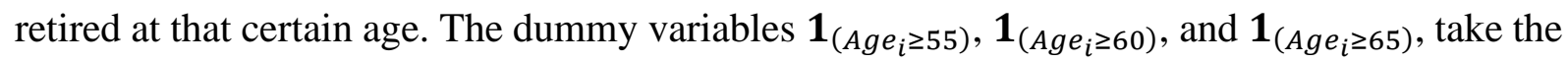
value 1 when individual $i$ is, respectively, at least 55, 60, or 65 years-old. Consequently, we estimate the following equation system:

$$
\left\{\begin{array}{c}
R_{2010, i}=\beta_{0}^{\prime}+\beta_{1}^{\prime} \mathbf{1}_{\left(\text {Age }_{i} \geq 55\right)}+\beta_{2}^{\prime} \mathbf{1}_{\left(A g e_{i} \geq 60\right)}+\beta_{3}^{\prime} \mathbf{1}_{\left(A g e_{i} \geq 65\right)}+\beta_{4}^{\prime} C_{i}^{\prime}+\varepsilon_{i}^{\prime} \\
Y_{2010, k, i}=\beta_{0}+\beta_{1} \widehat{R_{2010, l}}+\beta_{2} \text { Expo }_{b i o, l, i}+\beta_{3} R_{2010, i} \times \operatorname{Expo}_{b i o, l, i}+\beta_{4} C_{2010, i}^{\prime}+\beta_{5} C_{b i o, i}^{\prime}+\varepsilon_{i}
\end{array}\right.
$$

where $C_{i}^{\prime}$ in the first stage equation is a vector of all the explanatory variables in the second stage equation - with the exception of the retirement variable, of course. Empirically, to estimate this two-equation system, we set up a 2-stage model estimated by the generalized method of moments (GMM2S) estimator with heteroscedasticity-robust standard errors.

\subsubsection{Endogenous selection into job types}

Because our individuals are potentially (self-)selected into different types and severity of exposures to work strains, their exposure levels are most likely endogenous (the selection process itself being notably related to health status). This induces the variables for working conditions (including the interaction terms) to suffer from endogeneity as well. In order to handle this endogenous selection process, we use a matching method prior to setting up the instrumental variables, based on pre-conditions related to health status and employment. This 
allows us to consider exposure to detrimental working conditions as a random process in our sample. A coarsened exact matching (CEM) method is implemented (Blackwell et al., 2010). The main objective of this methodology is to reduce both univariate and global imbalances between treated and control groups according to several pre-treatment covariates. This offers two main advantages compared to other matching methods: it helps in coping effectively with the curse of dimensionality; and it reduces the model dependence of the results (Iacus et al., 2008). The end result is a weight variable that is then used in the estimation of model (2): the weight value for matched individuals equals $\frac{n_{s}^{O}}{n_{s}^{U}} \times \frac{N^{U}}{N^{O}}$, with $n_{s}$ representing the sample size for, respectively, the groups who are overexposed $(O)$ and underexposed $(U)$ to physical or psychosocial working conditions in stratum $s$ (a stratum being the pool of individuals sharing the same values for all the matching variables used); while $N$ is the total sample size for both groups. Unmatched individuals are weighted 0.

In a framework very similar to Defebvre (2018), matching pre-exposure variables are chosen so that they are relevant in terms of health status and position in the labour market. In addition, they help us cope with the (self-)selection bias (individuals sustaining higher levels of exposure are bound to be particularly resilient or, in contrast, they are particularly deprived of better opportunities in the labour market). Individuals are matched according to: their year of entry into the labour market (in order to get rid of both temporal heterogeneity related to generation/conjuncture effects and different exposures to pension system reforms); gender (Shmueli, 2003; Devaux et al., 2008); education level (because of important structural differences in the education of exposed individuals and also due to education's well-known protective role towards health status); health status before labour market entry (in order to better assess their initial health status and to cope with endogenous sorting in the labour market); and important events during childhood, which are aggregated into three dummy variables (problems with relatives, facing violence, and harsh material living conditions) because such childhood events clearly impact early outcomes of health status (Lindeboom et al. 2002; Case et al. 2005). Matching the samples on such variables is bound to limit the selection biases into employment and into different degrees of exposure, as a part of an individual's resilience to work strains is notably accounted for by proxy variables for their initial health capital. 


\section{Results}

\subsection{Matching results}

Table 2 presents several descriptive statistics for different groups of individuals, depending on their levels of exposure to detrimental physical and psychosocial working conditions (i.e., being part of either the overexposed or underexposed group). The first half of the table shows that individuals facing higher exposure levels than the sample average consistently have worse health status than the underexposed. The physically overexposed are also more often male and significantly less educated (this is less so in the case of psychosocial exposure). One of the most important results lies in the differences of early life conditions, which indicate that the future overexposed (physically or psychosocially) also experienced overall harsher childhood living conditions. In any case, because of these differences, the sample features potential (self)selection bias, suggesting that the possibility of choosing jobs is not identical, given one's own initial conditions.

After matching with CEM, over $90 \%$ of the initial sample is retained and all of these structural differences are nullified. The only difference is between the physically overexposed and underexposed regarding their years of entry into the labour market, which remains at . 04 of a year, i.e., roughly half a month and is obviously statistically insignificant. It should be noted that the differences in health status are slightly reduced but still remain quite large and statistically significant. 
Table 2: Unmatched and matched descriptive statistics

\begin{tabular}{|c|c|c|c|c|c|c|}
\hline \multirow{2}{*}{ Variable } & \multicolumn{3}{|c|}{ Average depending on physical exposure } & \multicolumn{3}{|c|}{ Average depending on psychosocial exposure } \\
\hline & Overexposed & Underexposed & Difference & Overexposed & Underexposed & Difference \\
\hline \multicolumn{7}{|c|}{ UNMATCHED DESCRIPTIVE STATISTICS } \\
\hline \multicolumn{7}{|l|}{ Health status } \\
\hline Poor SAH & .46 & .31 & $-.15 * * *$ & .44 & .32 & $-.11 * * *$ \\
\hline Chronic disease & .51 & .40 & $-.11 * * *$ & .51 & .41 & $-.10 * * *$ \\
\hline Activity limitation & .32 & .20 & $-.11 * * *$ & .30 & .22 & $-.08 * * *$ \\
\hline Anxiety disorder & .09 & .06 & $-.03 * * *$ & .09 & .05 & $-.04 * * *$ \\
\hline Depressive episode & .10 & .06 & $-.03 * * *$ & .11 & .06 & $-.05 * * *$ \\
\hline \multicolumn{7}{|l|}{ Matching variables } \\
\hline Entry year on labour market & 1967.4 & 1970.6 & $3.12 * * *$ & 1969.0 & 1969.6 & $.60^{* *}$ \\
\hline Male & .55 & .41 & $-.13 * * *$ & .47 & .46 & -.01 \\
\hline \multicolumn{7}{|l|}{ Education } \\
\hline - No education & .13 & .06 & $-.07 * * *$ & .10 & .08 & $-.02 * * *$ \\
\hline - Primary/secondary & .70 & .50 & $-.20 * * *$ & .58 & .57 & -.02 \\
\hline - Bachelor equivalent & .09 & .18 & $.09 * * *$ & .14 & .15 & .01 \\
\hline - Post graduate & .07 & .25 & $.18 * * *$ & .16 & .20 & $.03 * * *$ \\
\hline \multicolumn{7}{|l|}{ Childhood events } \\
\hline - Problems in relatives & .41 & .35 & $-.07 * * *$ & .42 & .35 & $-.08 * * *$ \\
\hline - Facing violence & .09 & .06 & $-.03 * * *$ & .11 & .05 & $-.06 * * *$ \\
\hline - Health problems & .09 & .08 & -.00 & .09 & .08 & -.01 \\
\hline - Poor material conditions & .29 & .20 & $-.08 * * *$ & .31 & .18 & $-.14 * * *$ \\
\hline $\mathbf{N}$ & \multicolumn{6}{|c|}{6472} \\
\hline \multicolumn{7}{|c|}{ MATCHED DESCRIPTIVE STATISTICS } \\
\hline \multicolumn{7}{|l|}{ Health status } \\
\hline Poor SAH & .45 & .34 & $-.11 * * *$ & .42 & .33 & $-.10 * * *$ \\
\hline Chronic disease & .50 & .42 & $-.08 * * *$ & .50 & .42 & $-.08 * * *$ \\
\hline Activity limitation & .31 & .22 & $-.09 * * *$ & .29 & .22 & $-.06 * * *$ \\
\hline Anxiety disorder & .08 & .05 & $-.04 * * *$ & .09 & .06 & $-.04 * * *$ \\
\hline Depressive episode & .09 & .06 & $-.03 * * *$ & .10 & .06 & $-.04 * * *$ \\
\hline \multicolumn{7}{|l|}{ Matching variables } \\
\hline Entry year on labour market & 1967.7 & 1967.7 & .04 & 1969.2 & 1969.2 & -.00 \\
\hline Male & .54 & .54 & .00 & .46 & .46 & -.00 \\
\hline \multicolumn{7}{|l|}{ Education } \\
\hline - No education & .11 & .11 & -.00 & .09 & .09 & .00 \\
\hline - Primary/secondary & .73 & .73 & -.00 & .62 & .62 & .00 \\
\hline - Bachelor equivalent & .08 & .08 & -.00 & .13 & .13 & -.00 \\
\hline - Post graduate & .07 & .07 & .00 & .16 & .16 & .00 \\
\hline \multicolumn{7}{|l|}{ Childhood events } \\
\hline - Problems in relatives & .40 & .40 & -.00 & .40 & .40 & -.00 \\
\hline - Facing violence & .06 & .06 & -.00 & .07 & .07 & .00 \\
\hline - Health problems & .07 & .07 & -.00 & .06 & .06 & .00 \\
\hline - Poor material conditions & .25 & .25 & -.00 & .28 & .28 & .00 \\
\hline $\mathbf{N}$ & & 5828 & & & 5954 & \\
\hline
\end{tabular}

Note. *** Significant at the $1 \%$ level. ** Significant at $5 \%$. Significant at $10 \%$.

Reading guide: The overexposed sample faced a higher number of years of exposure to detrimental working conditions than the whole sample's average, and vice versa for the underexposed sample.

Field: Santé et Itinéraire Professionnel survey, individuals aged 45-74 in 2010. 


\subsection{Main results}

\subsubsection{Validity of the results}

Regarding the three instruments used as exogeneity sources in the first stages of estimating our instrumental variables for the relationship between retirement and health status, they appear to be very strong predictors of the probability of being retired (Table 3 and Table 4). While being aged 55 and 65 increase the probability of being retired by, respectively, more than 6 and 10 percentage points $(p p)$, reaching age 60 is clearly the most relevant variable, with a related increase of around 50pp. This is confirmed by the resulting first-stage $F$ statistics, which are well above the rule-of-thumb value of 10 for decently relevant instruments, and they are in line with the intuitions given by Figure 1: Cumulative proportion of retirees in the sample according to age

. The validity of these instruments (i.e., the fact that they are not correlated with the error terms) is also verified by the Sargan-Hansen tests, which never reject the null hypothesis of correctly excluded instruments. It is also verified by the reduced-form models (models where the instruments are directly included in the main health status models), which indicate that neither age has a statistically significant effect on health status - conditional on the control variables. Finally, the matching method appears to reduce not only the role of exposures to detrimental working conditions, but most likely also the endogenous selection into certain types of jobs/careers, which is in line with what one would expect from nearly nullifying the structural differences between future overexposed and underexposed individuals before their entry into the labour market. Yet, these reductions take place while retaining close to $92 \%$ of the original sample.

\subsubsection{Nä̈ve results}

The odd-numbered columns in the first halves of Table 3 (physical exposures) and Table 4 (psychosocial exposures) give the results of the model (1) estimates by ordinary least squares and using heteroscedasticity-robust standard errors. First, looking at retirement for individuals who did not face detrimental working conditions during their career (given by $\widehat{\beta_{1}}$, i.e., when $\operatorname{Expo}_{\text {bio }, l, i}=0$ and, consequently, $R_{2010, i} \times E x p o_{b i o, l, i}=0$ ), it does not seem to bear any statistically significant effect on health status, except for a positive effect of a little more than $8 p p$ on the probability of declaring to have suffered from chronic diseases (column 3). 
Second, for non-retirees, the effect of exposure to detrimental working conditions is given by $\widehat{\beta_{2}}$, parameter of $\operatorname{Expo}_{b i o, l, i}$, i.e., when $R_{2010, i}=0$ and, consequently, $R_{2010, i} \times E_{x p o_{b i o, l, i}}=$ 0 , by which this effect overall consistently appears to be positive and highly statistically significant in the probability of declaring poor health conditions. More precisely, greater numbers of years experiencing exposures to physical strains seem to be especially correlated with general health status indicators (Table 3, columns 1,3, and 5), while the effect of psychosocial exposures seems slightly stronger for mental health conditions (Table 4, columns 7 and 9). For instance, the effect that exposure to the psychosocial strains of work has on the probability of anxiety in non-retired individuals amounts to $0.9 p p$ per year of exposure, meaning that someone exposed 10 years to these kinds of strains experiences an increase of $9 p p$ in his/her probability of anxiety disorders.

Third, for individuals who are overexposed to detrimental working conditions, the effect of retirement on health status (given by $\widehat{\beta_{1}}+\widehat{\beta_{3}}$ when $R_{2010, i}=1$ and $\operatorname{Expo}_{b i o, l, i} \neq 0$, i.e., $R_{2010, i} \times \operatorname{Expo}_{b i o, l, i} \neq 0$ ) is given as a linear function of the number of years of exposure. Because $\widehat{\beta_{1}}$ is almost never statistically significant, $\widehat{\beta_{3}}$ gives the overall effect of retirement on health status, which thus seems to exist only in exposed individuals, if these naïve estimations are to be believed. The effects are systematically negative and statistically significant, meaning that the effect of retirement is statistically different between exposed and non-exposed individuals. The effect of retirement on the probability of activity limitations for individuals exposed to years of physical exposures (Table 3, column 5) is $-0.5 p p$ per year of exposure, meaning that someone exposed 10 years to these kinds of strains experiences a decrease of $5 p p$ in his/her probability of declaring activity limitations after retirement. Conversely, $\widehat{\beta_{3}}$ can also be interpreted as the supplementary effect of exposure to detrimental working conditions for retired individuals, meaning that $\widehat{\beta_{2}}+\widehat{\beta_{3}}$ gives the effect of a year of exposure in the retired population. Thus, the marginal effect of a year of exposure to psychosocial strains on the probability of poor self-assessed health status amounts to $0.7 p p-0.3 p p=0.4 p p$, inducing a protective effect of retirement on health against exposure (Table 4, column 1).

Finally, the control covariates deliver several expected results. Among these results, ageing has a significant deteriorating effect on general health (SAH and activity limitations); education overall has a very sizeable protective effect, except for anxiety disorders (due to physical exposure); being self-employed (compared to private sector work) has a protective effect on physical health; and job stability overall has a protective effect. 


\subsubsection{Results of the matched instrumental variables}

The even-numbered columns in the first halves of Table 3 (physical exposures) and Table 4 (psychosocial exposures) give the results of the model (2) estimates using 2-stage generalized methods of moments with heteroscedasticity-robust standard errors. Furthermore, they are weighted with weights from the CEM method.

The changes induced by this new method are twofold. First, a major change can be observed in the effect of retirement on the non-exposed population, which becomes almost completely negative and statistically significant. This indicates that, after taking care of endogeneity biases, retirement is found to have a positive effect on SAH, anxiety, and depression, even in the nonexposed populations. This positive effect of retirement on the health of non-exposed individuals is quite similar in magnitude for people who are not exposed to physical or psychosocial strains. Second, after using the matching method on exposure levels, a small but general decrease occurs in magnitude regarding the effect of exposures on health. Yet, almost all the effects still remain statistically significant, both for $\widehat{\beta_{2}}$ (the effect of exposure on the non-retired) and $\widehat{\beta_{3}}$ (the supplementary effect of exposure on the retired).

On average, the duration of physical and psychosocial strains is, respectively, 8 and 6 years in our sample (Appendix 5). Thus, as an example, the mean effect of retirement on the probability of declaring anxiety disorders by an individual exposed to physical strains amounts to $\widehat{\beta_{1}}+$ $\left(\widehat{\beta_{3}} \times 8\right)=-6.3 p p+(-0.1 p p \times 8)=-7.1 p p($ Table 3 , column 8$)$. The greatest positive effect of retirement is observed on SAH, whatever the nature of the working conditions. On average, the decline represents 20.1pp (in the case of physical strains) and 16.3pp (psychosocial strains). In addition, the retirement effect on mental health is higher if the exposure is related to psychosocial strains rather than physical ones.

Conversely, one can say that the marginal effect of a year of exposure to detrimental psychosocial strains at work induces an increase in this probability of $\widehat{\beta_{2}}=0.8 p p$ for the nonretired and of only $\widehat{\beta_{2}}+\widehat{\beta_{3}}=0.3 p p$ in the retired, thus confirming a protective effect of retirement on health. Finally, very few changes are observed in the relationships between health and the other covariates.

\subsubsection{Heterogeneous effects of retirement, by gender and education level}

We can go further by exploring subsamples related to gender and education level (Table 5). As expected, men are in average more exposed to physical working conditions than women, at a 
rate of respectively 10 years versus 6 years. No clear gender gap is evident in regard to psychosocial risks. Women suffered from harsh psychosocial working conditions during 6 years while the duration reaches close to 7 years for males. When considering physical strains, education level comes into play in both men's and women's average length of exposure, with the male population's exposure to physical strains ranging from 16 years (no diploma) to 2 years (post-graduate). However, education level does not appear to play a protective role for psychosocial strains. Keeping in mind these differences of exposure, in particular to physical strains, the mean effect of retirement for such subcategories is as follows. Concerning physical exposures, the probability of self-reporting poor SAH decreases by $20.5 p p$ (for men) and by $19.7 p p$ (for women). When taking into account education level, retirement's influence on health proves to be significantly different via the crossed variable between retirement and years of exposure. The positive impact of retirement on health is higher for the low skilled, notably among men.

This is particularly true for chronic diseases and activity limitations, which are sensitive solely to the interaction between retirement status and the duration of physical exposure. In the male population with no diploma and exposed to physical constraints, retirement leads to a decline of $21.7 p p$ in the probability of declaring poor $\mathrm{SAH}$ and of $8 p p$ in chronic diseases, activity limitations, anxiety, and depression. In the male post-graduate group, the beneficial impact of retirement is weaker, with a decrease of $18.9 p p$ in the probability for $\mathrm{SAH}$, almost $7 p p$ for anxiety and depression, and only $1 p p$ for chronic diseases and activity limitations. In the female population, the social difference is less pronounced for the length of working conditions.

\subsubsection{Mechanisms}

Some particularly interesting conclusions can be made from these general results. First, retirement plays a protective role in $\mathrm{SAH}$, anxiety, and depression among non-exposed individuals. Second, physical strains seem to be particularly related to bad general health, while psychosocial risk factors are especially associated with mental health conditions (but also $\mathrm{SAH})$. Yet, each type of working condition seems to influence both types of health indicators, although to varying magnitudes. Third, for chronic diseases and activity limitations in particular, the entire effect of retirement pertains to the exposed population-meaning that retirement does not seem to relieve the non-exposed population from these two health conditions, but it does do so for the exposed population, especially unskilled men. This is probably related to the fact that these two indicators induce long-term illnesses with a high age- 
correlation and that retirement allows for recovery from only work-induced chronic diseases and activity limitations. Finally, what is probably the most interesting point: despite its protective effect on health, retirement does not seem to completely resorb the detrimental effect of work strains on health, especially among the most exposed individuals. 
Table 3: The effect of retirement on health status, according to physical exposure

\begin{tabular}{|c|c|c|c|c|c|c|c|c|c|c|}
\hline \multirow{2}{*}{ Variables } & \multicolumn{2}{|c|}{ Poor SAH } & \multicolumn{2}{|c|}{ Chronic diseases } & \multicolumn{2}{|c|}{ Activity limitations } & \multicolumn{2}{|c|}{ Anxiety } & \multicolumn{2}{|c|}{ Depression } \\
\hline & Naïve (1) & MIV (2) & Naïve (3) & MIV (4) & Naïve (5) & MIV (6) & Naïve (7) & MIV (8) & Naïve (9) & MIV (10) \\
\hline \multicolumn{11}{|c|}{ MAIN SPECIFICATIONS RESULTS } \\
\hline $\begin{array}{l}\text { Retirement \& exposure } \\
\text { Retired } \\
\text { (ref: } \text { not retired) } \\
\text { Physical exposure } \\
\text { (in years) } \\
\text { Retired } \times \text { Physical exp. } \\
\text { (crossed variable) }\end{array}$ & $\begin{array}{c}.015 \\
.020 \\
.008 * * * \\
.001 \\
-.003 * * \\
.001 \\
\end{array}$ & $\begin{array}{c}-.185 * * * \\
.067 \\
.005 * * * \\
.001 \\
-.002 * \\
.001 \\
\end{array}$ & $\begin{array}{c}.078 * * * \\
.022 \\
.007 * * * \\
.001 \\
-.005 * * * \\
.001 \\
\end{array}$ & $\begin{array}{c}-.073 \\
.067 \\
.007 * * * \\
.001 \\
-.005 * * * \\
.002 \\
\end{array}$ & $\begin{array}{c}.022 \\
.019 \\
.006 * * * \\
.001 \\
-.005 * * * \\
.001 \\
\end{array}$ & $\begin{array}{c}-.076 \\
.056 \\
.005 * * * \\
.001 \\
-.005 * * * \\
.001 \\
\end{array}$ & $\begin{array}{c}-.001 \\
.011 \\
.003 * * * \\
.001 \\
-.002 * * * \\
.000 \\
\end{array}$ & $\begin{array}{c}-.063 * * \\
.029 \\
.003 * * * \\
.001 \\
-.001 * * \\
.000\end{array}$ & $\begin{array}{c}-.005 \\
.011 \\
.003 * * * \\
.001 \\
-.002 * * * \\
.000 \\
\end{array}$ & $\begin{array}{c}-.065 * * \\
.031 \\
.002 * * \\
.001 \\
-.001 * \\
.000 \\
\end{array}$ \\
\hline $\begin{array}{l}\text { Demographics } \\
\text { Male } \\
\text { (ref: female) } \\
\text { Age } \\
\text { (in years) } \\
\text { Age squared } \\
\text { (in square years) } \\
\text { Children } \\
\text { (ref: none) }\end{array}$ & $\begin{array}{l}-.016 \\
.012 \\
.019 * \\
.011 \\
-.000 \\
.000 \\
-.019 \\
.020 \\
\end{array}$ & $\begin{array}{c}-.007 \\
.016 \\
.042 * * * \\
.014 \\
-.001 * * \\
.000 \\
-.021 \\
.026 \\
\end{array}$ & $\begin{array}{c}-.018 \\
.013 \\
.017 \\
.011 \\
-.000 \\
.000 \\
-.027 \\
.020 \\
\end{array}$ & $\begin{array}{c}-.031 * \\
.017 \\
.026 * \\
.014 \\
-.000 \\
.000 \\
-.054 * \\
.028 \\
\end{array}$ & $\begin{array}{c}.003 \\
.011 \\
.022 * * \\
.010 \\
-.001 * \\
.000 \\
-.001 \\
.018 \\
\end{array}$ & $\begin{array}{c}.003 \\
.015 \\
.024 * \\
.012 \\
-.000 \\
.000 \\
-.036 * \\
.021 \\
\end{array}$ & $\begin{array}{c}-.040 * * * \\
.006 \\
.002 \\
.006 \\
-.000 \\
.000 \\
.013 \\
.009 \\
\end{array}$ & $\begin{array}{c}-.037 * * * \\
.008 \\
.001 \\
.007 \\
-.000 \\
.000 \\
.020 * * \\
.009 \\
\end{array}$ & $\begin{array}{c}-.032 * * * \\
.007 \\
.015 * * \\
.006 \\
-.001 * * * \\
.000 \\
.022 * * \\
.009 \\
\end{array}$ & $\begin{array}{c}-.038 * * * \\
.001 \\
.013 * \\
-.007 \\
-.000 \\
.000 \\
.023 * * \\
.010 \\
\end{array}$ \\
\hline $\begin{array}{l}\text { Education } \\
\text { Primary/secondary } \\
\text { (ref: } \text { no education) } \\
\text { Bachelor equivalent } \\
\text { (ref: } \text { no education) } \\
\text { Post graduate } \\
\text { (ref: } \text { no education) } \\
\end{array}$ & $\begin{array}{c}-.122 * * * \\
.021 \\
-.130 * * * \\
.025 \\
-.240 * * * \\
.024 \\
\end{array}$ & $\begin{array}{c}-.132 * * * \\
.031 \\
-.171 * * * \\
.036 \\
-.259 * * * \\
.036 \\
\end{array}$ & $\begin{array}{c}-.041 * * \\
.021 \\
-.011 \\
.026 \\
-.039 \\
.025 \\
\end{array}$ & $\begin{array}{l}-.022 \\
.031 \\
-.009 \\
.036 \\
-.013 \\
.037 \\
\end{array}$ & $\begin{array}{c}-.050 * * \\
.024 \\
-.046^{*} \\
.024 \\
-.101 * * * \\
.022 \\
\end{array}$ & $\begin{array}{c}-.035 \\
.028 \\
-.038 \\
.033 \\
-.089 * * * \\
.032 \\
\end{array}$ & $\begin{array}{c}-.019 \\
.012 \\
-.000 \\
.014 \\
-.022 \\
.013 \\
\end{array}$ & $\begin{array}{l}-.015 \\
.0167 \\
-.009 \\
.020 \\
-.017 \\
.019 \\
\end{array}$ & $\begin{array}{c}-.048 * * * \\
.014 \\
-.040 * * \\
.016 \\
-.069 * * * \\
.015 \\
\end{array}$ & $\begin{array}{c}-.054 * * * \\
.020 \\
-.056 * * * \\
.023 \\
-.085 * * * \\
.022 \\
\end{array}$ \\
\hline $\begin{array}{l}\text { Employment } \\
\text { Public sector } \\
\text { (ref: private sector) } \\
\text { Self-employed } \\
\text { (ref: private sector) } \\
\text { Long-term jobs } \\
\text { (ref: short-term jobs) } \\
\text { Stable career } \\
\text { (ref: } \text { unstable career) }\end{array}$ & $\begin{array}{c}-.024 \\
.016 \\
-.076 * * * \\
.023 \\
-.097 * * * \\
.012 \\
-.035 * * * \\
.012 \\
\end{array}$ & $\begin{array}{c}-.033 \\
.023 \\
-.102 * * * \\
.033 \\
-.109 * * * \\
.021 \\
-.029 * \\
.016 \\
\end{array}$ & $\begin{array}{c}-.004 \\
.018 \\
-.049 * * \\
.025 \\
-.072 * * * \\
.016 \\
-.019 \\
.013 \\
\end{array}$ & $\begin{array}{c}-.010 \\
.023 \\
-.042 \\
.034 \\
-.095 * * * \\
.021 \\
-.008 \\
.017 \\
\end{array}$ & $\begin{array}{c}-.025 * \\
.014 \\
-.060 * * * \\
.019 \\
-.084 * * * \\
.015 \\
-.020 * \\
.011 \\
\end{array}$ & $\begin{array}{c}-.048 * * \\
.019 \\
-.059 * * \\
.029 \\
-.100 * * * \\
.020 \\
-.001 \\
.014 \\
\end{array}$ & $\begin{array}{c}.008 \\
.009 \\
-.013 \\
.011 \\
-.036 * * * \\
.009 \\
-.002 \\
.007 \\
\end{array}$ & $\begin{array}{c}.003 \\
.010 \\
-.009 \\
.016 \\
-.031 * * * \\
.012 \\
-.004 \\
.008 \\
\end{array}$ & $\begin{array}{c}.004 \\
.010 \\
-.021 * \\
.012 \\
-.046 * * * \\
.010 \\
-.013 * \\
.007 \\
\end{array}$ & $\begin{array}{c}.004 \\
.011 \\
-.008 \\
.018 \\
-.040 * * * \\
.012 \\
-.009 \\
.009 \\
\end{array}$ \\
\hline $\mathbf{N}$ & 6472 & 5828 & 6472 & 5828 & 6472 & 5828 & 6472 & 5828 & 6472 & 5828 \\
\hline Sargan-Hansen stat. & - & .430 & - & 1.500 & - & .386 & - & .717 & - & .118 \\
\hline \% matched & \multicolumn{10}{|c|}{91.59} \\
\hline \multicolumn{11}{|c|}{ FIRST-STAGE RESULTS FOR MIV MODELS (EXTRACT) } \\
\hline $\begin{array}{l}\text { Age above } 55 \\
\text { (ref: below 55) } \\
\text { Age above } 60 \\
\text { (ref: below } 60 \text { ) } \\
\text { Age above } 65 \\
\text { (ref: below } 65 \text { ) }\end{array}$ & & & & & $\begin{array}{r}.06 \\
.0 \\
.47 \\
.0 \\
.10 \\
.0\end{array}$ & $\begin{array}{l}* * * \\
4 \\
: * * \\
5 \\
* * * \\
9\end{array}$ & & & & \\
\hline Controls & \multicolumn{10}{|c|}{ Yes } \\
\hline F-stat. & \multicolumn{10}{|c|}{$164.610 * * *$} \\
\hline $\mathbf{N}$ & \multicolumn{10}{|c|}{5828} \\
\hline \multicolumn{11}{|c|}{ REDUCED FORMS RESULTS FOR MIV MODELS (EXTRACT) } \\
\hline $\begin{array}{l}\text { Age above } 55 \\
\text { (ref: below } 55 \text { ) } \\
\text { Age above } 60 \\
\text { (ref: below } 60 \text { ) } \\
\text { Age above } 65 \\
\text { (ref: below } 65 \text { ) }\end{array}$ & \multicolumn{2}{|c|}{$\begin{array}{l}-.014 \\
.033 \\
-.047 \\
.042 \\
-.045 \\
.044\end{array}$} & $\begin{array}{l}.0 \\
.0 \\
.0 \\
.0 \\
.0\end{array}$ & & \multicolumn{2}{|c|}{$\begin{array}{c}.008 \\
.030 \\
-.035 \\
.030 \\
-.020 \\
.036\end{array}$} & \multicolumn{2}{|c|}{$\begin{array}{l}-.017 \\
.018 \\
-.021 \\
.014 \\
-.012 \\
.015\end{array}$} & \multicolumn{2}{|c|}{$\begin{array}{r}-.009 \\
.020 \\
-.019 \\
.014 \\
-.011 \\
.016\end{array}$} \\
\hline Controls & \multicolumn{10}{|c|}{ Yes } \\
\hline $\mathbf{N}$ & \multicolumn{10}{|c|}{5828} \\
\hline
\end{tabular}

Note. Naive models estimated by heteroscedasticity-robust OLS, matched instrumental variable models (MIV) estimated by heteroscedasticity-robust weighted two-stage GMM. *** Significant at the $1 \%$ level. ** Significant at 5\%. * Significant at $10 \%$. Standard errors in italics.

Reading guide: OLS models show a positive effect of 7.8pp on the probability of declaring suffering from chronic diseases for individuals not exposed to physically detrimental working conditions.

Field: Santé et Itinéraire Professionnel survey, individuals aged 45-74 in 2010. 
Table 4: The effect of retirement on health status, according to psychosocial exposure

\begin{tabular}{|c|c|c|c|c|c|c|c|c|c|c|}
\hline \multirow{2}{*}{ Variables } & \multicolumn{2}{|c|}{ Poor SAH } & \multicolumn{2}{|c|}{ Chronic diseases } & \multicolumn{2}{|c|}{ Activity limitations } & \multicolumn{2}{|c|}{ Anxiety } & \multicolumn{2}{|c|}{ Depression } \\
\hline & Naïve (1) & MIV (2) & Naïve (3) & MIV (4) & Naïve (5) & MIV (6) & Naïve (7) & MIV (8) & Naïve (9) & MIV (10) \\
\hline \multicolumn{11}{|c|}{ MAIN SPECIFICATIONS RESULTS } \\
\hline $\begin{array}{l}\text { Retirement \& exposure } \\
\text { Retired } \\
\text { (ref: } \text { not retired) } \\
\text { Psychosocial exposure } \\
\text { (in years) } \\
\text { Retired } \times \text { Psycho. exp. } \\
\text { (crossed variable) } \\
\end{array}$ & $\begin{array}{c}.007 \\
.020 \\
.007 * * * \\
.001 \\
-.003 * * \\
.001 \\
\end{array}$ & $\begin{array}{c}-.163 * * * \\
.054 \\
.004 * * * \\
.001 \\
-.002 \\
.002 \\
\end{array}$ & $\begin{array}{c}.077 * * * \\
.022 \\
.006 * * * \\
.001 \\
-.004 * * * \\
.001 \\
\end{array}$ & $\begin{array}{c}-.080 \\
.056 \\
.006 * * * \\
.001 \\
-.004 * * \\
.002 \\
\end{array}$ & $\begin{array}{c}.021 \\
.019 \\
.006^{* * *} \\
.001 \\
-.004 * * * \\
.001 \\
\end{array}$ & $\begin{array}{c}-.072 \\
.050 \\
.005 * * * \\
.001 \\
-.004 * * * \\
.001 \\
\end{array}$ & $\begin{array}{c}-.006 \\
.010 \\
.009^{* * *} \\
.001 \\
-.006 * * * \\
.001 \\
\end{array}$ & $\begin{array}{c}-.065^{* *} \\
.032 \\
.008 * * * \\
.002 \\
-.005 * * * \\
.001 \\
\end{array}$ & $\begin{array}{c}-.012 \\
.011 \\
.008 * * * \\
.001 \\
-.005 * * * \\
.001 \\
\end{array}$ & $\begin{array}{c}-.068 * * \\
.031 \\
.007 * * * \\
.002 \\
-.005 * * * \\
.001 \\
\end{array}$ \\
\hline $\begin{array}{l}\text { Demographics } \\
\text { Male } \\
\text { (ref: female) } \\
\text { Age } \\
\text { (in years) } \\
\text { Age squared } \\
\text { (in square years) } \\
\text { Children } \\
\text { (ref: none) } \\
\end{array}$ & $\begin{array}{l}-.003 \\
.012 \\
.019 * \\
.000 \\
-.000 \\
.000 \\
-.020 \\
.020\end{array}$ & $\begin{array}{l}-.001 \\
.015 \\
.032 * * \\
.013 \\
-.001 * \\
.000 \\
-.011 \\
.023 \\
\end{array}$ & $\begin{array}{l}-.007 \\
.013 \\
.017 \\
.011 \\
-.000 \\
.000 \\
-.028 \\
.020\end{array}$ & $\begin{array}{l}-.015 \\
.015 \\
.025^{*} \\
.013 \\
-.000 \\
.000 \\
-.030 \\
.024\end{array}$ & $\begin{array}{l}.014 \\
.011 \\
.022 * * \\
.010 \\
-.001 * \\
.000 \\
-.003 \\
.018 \\
\end{array}$ & $\begin{array}{l}.012 \\
.013 \\
.024 * * \\
.012 \\
-.000 \\
.000 \\
.008 \\
.020 \\
\end{array}$ & $\begin{array}{l}-.036 * * * \\
.006 \\
.002 \\
.006 \\
-.000 \\
.000 \\
.013 \\
.009 \\
\end{array}$ & $\begin{array}{c}-.040 * * * \\
.008 \\
.004 \\
.007 \\
-.000 \\
.000 \\
.018 * \\
.010 \\
\end{array}$ & $\begin{array}{l}-.029 * * * \\
.007 \\
.015 * * * \\
.006 \\
-.001 * * * \\
.000 \\
.022 * * \\
.009 \\
\end{array}$ & $\begin{array}{l}-.028 * * * \\
.008 \\
.020 * * * \\
.007 \\
-.001 * \\
.000 \\
.019 * \\
.011 \\
\end{array}$ \\
\hline $\begin{array}{l}\text { Education } \\
\text { Primary/secondary } \\
\text { (ref: no education) } \\
\text { Bachelor equivalent } \\
\text { (ref: no education) } \\
\text { Post graduate } \\
\text { (ref: no education) } \\
\end{array}$ & $\begin{array}{c}-.130 * * * \\
.021 \\
-.162 * * * \\
.025 \\
-.277 * * * \\
.023 \\
\end{array}$ & $\begin{array}{c}-.131 * * * \\
.030 \\
-.187 * * * \\
.034 \\
-.287 * * * \\
.032 \\
\end{array}$ & $\begin{array}{c}-.047 * * \\
.021 \\
-.037 \\
.026 \\
-.080 * * * \\
.025 \\
\end{array}$ & $\begin{array}{c}-.043 \\
.029 \\
-.057 * \\
.034 \\
-.088 * * * \\
.033 \\
\end{array}$ & $\begin{array}{c}-.056 * * * \\
.0200 \\
-.071 * * * \\
.023 \\
-.131 * * * \\
.022 \\
\end{array}$ & $\begin{array}{c}-.017 \\
.027 \\
-.036 \\
.031 \\
-.111^{* * *} \\
.029 \\
\end{array}$ & $\begin{array}{c}-.020 * \\
.012 \\
-.009 \\
.014 \\
-.032 * * \\
.013 \\
\end{array}$ & $\begin{array}{c}-.032 * \\
.019 \\
-.019 \\
.021 \\
-.037 * \\
.020 \\
\end{array}$ & $\begin{array}{c}-.048 * * * \\
.014 \\
-.047 * * * \\
.016 \\
-.077 * * * \\
.015 \\
\end{array}$ & $\begin{array}{c}-.052 * * \\
.020 \\
-.044 * \\
.022 \\
-.074 * * * \\
.021 \\
\end{array}$ \\
\hline $\begin{array}{l}\text { Employment } \\
\text { Public sector } \\
\text { (ref: private sector) } \\
\text { Self-employed } \\
\text { (ref: private sector) } \\
\text { Long-term jobs } \\
\text { (ref: short-term jobs) } \\
\text { Stable career } \\
\text { (ref: unstable career) }\end{array}$ & $\begin{array}{c}-.023 \\
.016 \\
-.075 * * * \\
.023 \\
-.095 * * * \\
.016 \\
-.036 * * * \\
.012 \\
\end{array}$ & $\begin{array}{c}-.030 \\
.020 \\
-.100 * * * \\
.029 \\
-.083 * * * \\
.020 \\
-.023 \\
.015 \\
\end{array}$ & $\begin{array}{c}-.004 \\
.018 \\
-.048 * \\
.025 \\
-.070 * * * \\
.016 \\
-.019 \\
.013 \\
\end{array}$ & $\begin{array}{c}.012 \\
.021 \\
-.019 \\
.033 \\
-.082 * * * \\
.021 \\
-.013 \\
.015 \\
\end{array}$ & $\begin{array}{c}-.025 * \\
.014 \\
-.060 * * * \\
.019 \\
-.082 * * * \\
.015 \\
-.021 * \\
.011 \\
\end{array}$ & $\begin{array}{c}-.034 * \\
.018 \\
-.072 * * * \\
.026 \\
-.071 * * * \\
.018 \\
-.003 \\
.013 \\
\end{array}$ & $\begin{array}{c}.010 \\
.009 \\
-.011 \\
.011 \\
-.037 * * * \\
.001 \\
-.003 \\
.007 \\
\end{array}$ & $\begin{array}{c}.002 \\
.011 \\
-.017 \\
.015 \\
-.027 * * \\
.012 \\
-.001 \\
.008 \\
\end{array}$ & $\begin{array}{c}.005 \\
.009 \\
-.018 \\
.012 \\
-.048 * * * \\
.010 \\
-.011 \\
.007 \\
\end{array}$ & $\begin{array}{c}.008 \\
.020 \\
-.008 \\
.011 \\
-.036 * * * \\
.013 \\
-.013 \\
.009 \\
\end{array}$ \\
\hline $\mathbf{N}$ & 6472 & 5954 & 6472 & 5954 & 6472 & 5954 & 6472 & 5954 & 6472 & 5954 \\
\hline Sargan-Hansen stat. & - & .845 & - & .290 & - & .965 & - & 1.178 & - & 1.091 \\
\hline$\%$ matched & \multicolumn{10}{|c|}{92.00} \\
\hline \multicolumn{11}{|c|}{ FIRST-STAGE RESULTS FOR MIV MODELS (EXTRACT) } \\
\hline $\begin{array}{l}\text { Age above } 55 \\
\text { (ref: below } 55) \\
\text { Age above } 60 \\
\text { (ref: below } 60 \text { ) } \\
\text { Age above } 65 \\
\text { (ref: below } 65 \text { ) }\end{array}$ & & & & & $\begin{array}{r}.06 \\
.0 \\
.50 \\
.0 \\
.12 \\
.0\end{array}$ & $\begin{array}{l}* * * \\
4 \\
* * * \\
0 \\
* * * \\
8\end{array}$ & & & & \\
\hline Controls & \multicolumn{10}{|c|}{ Yes } \\
\hline F-stat. & \multicolumn{10}{|c|}{209.12} \\
\hline $\mathbf{N}$ & \multicolumn{10}{|c|}{5954} \\
\hline \multicolumn{11}{|c|}{ REDUCED FORMS RESULTS FOR MIV MODELS (EXTRACT) } \\
\hline $\begin{array}{l}\text { Age above } 55 \\
\text { (ref: below 55) } \\
\text { Age above } 60 \\
\text { (ref: below 60) } \\
\text { Age above } 65 \\
\text { (ref: below 65) }\end{array}$ & \multicolumn{2}{|c|}{$\begin{array}{l}.019 \\
.031 \\
-.040 \\
.030 \\
-.047 \\
.034\end{array}$} & & & $\begin{array}{l}-.0 \\
.0 \\
-.0 \\
.0 \\
-.0 \\
.0\end{array}$ & $\begin{array}{l}17 \\
8 \\
35 \\
7 \\
47 \\
2 \\
\end{array}$ & & & $\begin{array}{l}-.0 \\
.0 \\
-.0 \\
.0 \\
-.0 \\
.0\end{array}$ & \\
\hline Controls & & & & & & & & & & \\
\hline $\mathbf{N}$ & & & & & & & & & & \\
\hline
\end{tabular}

Note. Naïve models estimated by heteroscedasticity-robust OLS, matched instrumental variables models (MIV) estimated by heteroscedasticity-robust weighted two-stage GMM. *** Significant at the $1 \%$ level. ** Significant at 5\%. * Significant at $10 \%$. Standard errors in italics.

Reading guide: MIV models show a negative effect of $16.3 p p$ on the probability of declaring poor levels of self-assessed health status for individuals not exposed to psychosocially detrimental working conditions.

Field: Santé et Itinéraire Professionnel survey, individuals aged 45-74 in 2010. 
Table 5: The effect of retirement on retirees' health at conditional mean exposure levels, by gender and education level

\begin{tabular}{|c|c|c|c|c|c|c|c|c|c|c|}
\hline \multirow{2}{*}{$\begin{array}{l}\text { Education } \\
\text { Exposure } \\
\end{array}$} & \multicolumn{2}{|c|}{ No education } & \multicolumn{2}{|c|}{ Primary/secondary } & \multicolumn{2}{|c|}{ Bachelor equivalent } & \multicolumn{2}{|c|}{ Post graduate } & \multicolumn{2}{|c|}{ Total } \\
\hline & Physical & Psychosocial & Physical & Psychosocial & Physical & Psychosocial & Physical & Psychosocial & Physical & Psychosocial \\
\hline \multicolumn{11}{|c|}{ POOR SAH } \\
\hline Men & -.21698 & -.163 & -.21006 & -.163 & -.19476 & -.163 & -.1897 & -.163 & -.20528 & -.163 \\
\hline Women & -.20488 & -.163 & -.19962 & -.163 & -.19192 & -.163 & -.19088 & -.163 & -.1971 & -.163 \\
\hline Total & -.21098 & -.163 & -.20468 & -.163 & -.1931 & -.163 & -.19038 & -.163 & -.20088 & -.163 \\
\hline \multicolumn{11}{|c|}{ CHRONIC DISEASES } \\
\hline Men & -.07995 & -.0322 & -.06265 & -.02736 & -.0244 & -.02696 & -.01175 & -.02136 & -.0507 & -.0268 \\
\hline Women & -.0497 & -.02792 & -.03655 & -.0254 & -.0173 & -.02052 & -.0147 & -.01904 & -.03025 & -.02352 \\
\hline Total & -.06495 & -.03008 & -.0492 & -.02632 & -.02025 & -.0232 & -.01345 & -.02 & -.0397 & -.02504 \\
\hline \multicolumn{11}{|c|}{ ACTIVITY LIMITATIONS } \\
\hline Men & -.07995 & -.0322 & -.06265 & -.02736 & -.0244 & -.02696 & -.01175 & -.02136 & -.0507 & -.0268 \\
\hline Women & -.0497 & -.02792 & -.03655 & -.0254 & -.0173 & -.02052 & -.0147 & -.01904 & -.03025 & -.02352 \\
\hline Total & -.06495 & -.03008 & -.0492 & -.02632 & -.02025 & -.0232 & -.01345 & -.02 & -.0397 & -.02504 \\
\hline \multicolumn{11}{|c|}{ ANXIETY } \\
\hline Men & -.07899 & -.10525 & -.07553 & -.0992 & -.06788 & -.0987 & -.06535 & -.0917 & -.07314 & -.0985 \\
\hline Women & -.07294 & -.0999 & -.07031 & -.09675 & -.06646 & -.09065 & -.06594 & -.0888 & -.06905 & -.0944 \\
\hline Total & -.07599 & -.1026 & -.07284 & -.0979 & -.06705 & -.094 & -.06569 & -.09 & -.07094 & -.0963 \\
\hline \multicolumn{11}{|c|}{ DEPRESSION } \\
\hline Men & -.08099 & -.10825 & -.07753 & -.1022 & -.06988 & -.1017 & -.06735 & -.0947 & -.07514 & -.1015 \\
\hline Women & -.07494 & -.1029 & -.07231 & -.09975 & -.06846 & -.09365 & -.06794 & -.0918 & -.07105 & -.0974 \\
\hline Total & -.07799 & -.1056 & -.07484 & -.1009 & -.06905 & -.097 & -.06769 & -.093 & -.07294 & -.0993 \\
\hline
\end{tabular}

Reading guide: The effect of retirement on the probability of declaring poor SAH among men with no education and exposed to the average level of physical exposure (conditional on education level and gender) is $-21.69 p p$.

Field: Santé et Itinéraire Professionnel survey, individuals aged 45-74 in 2010. 


\section{Discussion}

Our findings underline an overall positive short-term effect of retirement on health status, especially among lower-skilled workers and those retiring from highly demanding careers. Essentially, we find that retirement is all the more beneficial to health when people retire from physically or psychosocially arduous careers, particularly in terms of chronic diseases and activity limitations - for which these effects are evident only in the exposed population. This indicates that working conditions are essential in explaining the magnitude of retirement's positive health effects, but they can also shed light on some of the contradictory effects found in the literature. After controlling for endogeneity biases and short-term benefits in the overall French case, these results tend to reject the "retirement blues" assumption and favour the concept of "well deserved retirement".

Three main specificities concerning our dataset can explain these results.

The first specificity concerns the retirement age, which is comparatively lower in France (age 62 , whereas the standard age is 65 in most other countries), which converges with better results in terms of life expectancy at age 65. Yet, according to data from the European Working Conditions Survey, French retirees also appear to face poor physical and environmental working conditions in comparison to the European average. The average physical environment index for the EU28 rates approximately 84 out of 100, indicating somewhat few exposures to a variety of physical and environmental strains; whereas the French score amounts to only 79 out of 100, indicating significantly higher levels of exposure (Eurofound, 2017). Based on SHARE data, Celidoni et al. (2017) and Mazzonna and Peracchi (2017) show that, for people retiring as soon as possible or working in more physically demanding occupations, retirement has a positive effect on cognitive abilities. French retirees thus happen to be overrepresented in both of these groups, which explains the positive effect of retirement on this population.

The second specificity concerns French retirees tending to have more wealth relative to their European counterparts, by which they are thus more able to invest in their health status after retirement. The net replacement rate is $68 \%$, which places France among the most generous countries, along with Italy and Sweden. As a consequence, the poverty rate among the elderly is the lowest among most countries (3.8\% in France compared to $12.6 \%$ for the OECD). Thus, thanks to the French welfare state, retirees' health status and well-being therefore seem to be more protected, and this could partially explain the divergence between our results and others in the literature (Coe and Lindeboom 2008; Gorry et al. 2018). 
The final and third specificity relates to the age threshold of our sample. As stressed by Mazzonna and Peracchi (2017), years spent in retirement play an important role: the longer one is retired, the worse the effect on health status. In this study, we estimate the effect of retirement around thresholds of 55, 60, and 65 years of age, i.e., the short-term effect of retirement. As such, the retirees in our sample may have been relieved from their strenuous work lives but did not spend enough time in retirement to experience a potentially detrimental effect, particularly on their cognitive abilities.

Several limitations can be noted. As we do not rely on panel data estimators per se, we are unable to completely account for individual unobserved heterogeneity using fixed effects. Even though this should not matter within the framework of our instrumental variables, panel data would have allowed implementing differentiated trends to the left and right of the thresholds (in a Regression Discontinuity Design fashion), although at the cost of temporal distance and sample sizes. In addition, we cannot determine precisely whether the mean effect of retirement on health status differs according to distance from the retirement shock. Of course, because we are working with retrospective, declarative data from retirement-age individuals, the elderliness of this specific population may cause the data to suffer from recall biases or even justification/conception biases. This could be especially true when considering conceptual differences related to different generations or even when accounting for complex and highly fragmented careers. For example, one could suspect an endogenous justification bias, in which people choosing to retire may declare worse working conditions. In such a case, the observed detrimental effect of working conditions on health would bias downwards due to not-yet-retired people — who are in better health (see Table 1) — being overrepresented in the most exposed. It is not possible to completely manage such biases, although they may be reduced thanks to our econometric strategy, which uses several control variables for individual careers and matches individuals according to year of labour market entry (i.e., their generation) and education level (a decisive factor in memory biases). Nevertheless, it should be noted that simple occupational information tends to be recalled rather accurately, even over longer periods (Berney and Blane 1997). Finally, our models assume that health status is a continuous function of exposures to detrimental working conditions, which may or may not be the case.

\section{Conclusion}

This study measures the causal effect of retirement on health status by enacting a mixed econometric strategy that takes into account the endogenous nature of the retirement-health 
relationship and the role of past work strains. To our knowledge, this is the only paper that comprehensively considers the whole work trajectory while giving insights into the role played by arduous careers in the effect of retirement on health status.

Delaying retirement ages may therefore induce health-related risks, as retirement is evidently one important tool for relieving workers from their potentially poor working conditions. In that sense, postponing legal retirement ages may be unsuccessful in balancing pension systems, simply due primarily to the consequences of these reforms for health status at old ages, but also because exposed workers may be unable to even reach these higher thresholds while continuing to work. In concert with extensions to the contribution period or reversing retiree status, which has recently become increasingly desirable in Europe in recent years (Barnay, 2016), preventive measures for work strains should be adopted or, at least, differentiated retirement schemes should be established according to the nature and intensity of a pensioner's entire work life. This is all the more important because even though retirement allows for some health recovery after an arduous career, it fails to erase all the effects on health from exposure to physical and psychosocial strains. 


\section{REFERENCES}

Bahu M, Coutrot T, Mermilliod C, Rouxel C (2012) Appréhender les interactions entre la santé et la vie professionnelle et leur éventuel décalage temporel, un premier bilan d'une enquête innovante : SIP. Document de travail Drees

Barnay T (2016) Health, work and working conditions: a review of the European economic literature. The European Journal of Health Economics 17:693-709. https://doi.org/10.1007/s10198-015-0715-8

Barnay T, Duguet E, Le Clainche C, et al (2015) The Impact of a Disability on Labour Market Status: A Comparison of the Public and Private Sectors. Annals of Economics and Statistics 39. https://doi.org/10.15609/annaeconstat2009.119-120.39

Behncke S (2012) Does retirement trigger ill health? Health Economics 21:282-300. https://doi.org/10.1002/hec.1712

Berney LR, Blane DB (1997) Collecting retrospective data: Accuracy of recall after 50 years judged against historical records. Social Science \& Medicine 45:1519-1525. https://doi.org/10.1016/S0277-9536(97)00088-9

Blackwell M, Iacus S, King G, Porro G (2010) cem: Coarsened Exact Matching in Stata

Blake, Garrouste (2019) Collateral Effects of a Pension Reform in France. Annals of Economics and Statistics 57. https://doi.org/10.15609/annaeconstat2009.133.0057

Blake H, Garrouste C (2012) Collateral effects of a pension reform in France. Health Econometrics and Data Group Working Paper

Bonsang E, Adam S, Perelman S (2012) Does retirement affect cognitive functioning? Journal of Health Economics 31:490-501. https://doi.org/10.1016/j.jhealeco.2012.03.005

Bound J, Waidmann T (2007) Estimating the Health Effects of Retirement. Working Paper

Case A, Fertig A, Paxson C (2005) The lasting impact of childhood health and circumstance. J Health Econ 24:365-389. https://doi.org/10.1016/j.jhealeco.2004.09.008

Celidoni M, Dal Bianco C, Weber G (2017) Retirement and cognitive decline. A longitudinal analysis using SHARE data. Journal of Health Economics 56:113-125. https://doi.org/10.1016/j.jhealeco.2017.09.003

Charles KK (2002) Is Retirement Depressing?: Labor Force Inactivity and Psychological WellBeing in Later Life. National Bureau of Economic Research, Cambridge, MA

Coe NB, Lindeboom M (2008) Does Retirement Kill You? Evidence from Early Retirement Widows. Netspar discussion paper

Coe NB, von Gaudecker H-M, Lindeboom M, Maurer J (2012) THE EFFECT OF RETIREMENT ON COGNITIVE FUNCTIONING: THE EFFECT OF RETIREMENT ON COGNITIVE FUNCTIONING. Health Econ 21:913-927. https://doi.org/10.1002/hec.1771

Coe NB, Zamarro G (2011) Retirement effects on health in Europe. Journal of Health Economics 30:77-86. https://doi.org/10.1016/j.jhealeco.2010.11.002

Cottini E, Lucifora C (2013) Mental health and working conditions in Europe. ILRReview Working paper 4:958-989

Dave D, Rashad I, Spasojevic J (2008) The effects of retirement on physical and mental health outcomes. Southern Economic Journal 75:497-523

de Jonge J, Bosma H, Peter R, Siegrist J (2000) Job strain, effort-reward imbalance and employee well-being: a large-scale cross-sectional study. Social Science \& Medicine 50:1317-1327. https://doi.org/10.1016/S0277-9536(99)00388-3 
De Riccardis N (2012) Traitements de la non-réponse et calages pour l'enquête santé et itinéraire professionnel de 2010. Drees Working Paper

Defebvre É (2018) Harder, better, faster ... Yet stronger? Working conditions and selfdeclaration of chronic diseases. Health Economics 27:e59-e76. https://doi.org/10.1002/hec.3619

Devaux M, Jusot F, Sermet C, Tubeuf S (2008) Hétérogénéité sociale de déclaration de l'état de santé et mesure des inégalités de santé. RFAS 2008:29-47

Eibich P (2015) Understanding the effect of retirement on health: Mechanisms and heterogeneity. Journal of Health Economics 43:1-12. https://doi.org/10.1016/j.jhealeco.2015.05.001

Eurofound (2017) 6th European Working Conditions Survey Report - 2017 Update. Eurofound

Fletcher JM, Sindelar JL, Yamaguchi S (2011) Cumulative effects of job characteristics on health. Health Economics 20:553-570. https://doi.org/10.1002/hec.1616

Gorry A, Gorry D, Slavov SN (2018) Does retirement improve health and life satisfaction? Health Economics 27:2067-2086. https://doi.org/10.1002/hec.3821

Grip AD, Lindeboom M, Montizaan R (2012) Shattered Dreams: The Effects of Changing the Pension System Late in the Game*: MENTAL HEALTH EFFECTS OF A PENSION REFORM. The Economic Journal 122:1-25. https://doi.org/10.1111/j.14680297.2011.02486.x

Grossman M (1972) On the Concept of Health Capital and the Demand for Health. Journal of Political Economy 80:223-255

Hahn J, Todd P, Van der Klaauw W (2001) Identification and Estimation of Treatment Effects with a Regression-Discontinuity Design. Econometrica 69:201-209

Heller-Sahlgren G (2017) Retirement blues. Journal of Health Economics 54:66-78. https://doi.org/10.1016/j.jhealeco.2017.03.007

Iacus SM, King G, Porro G (2008) Matching for Causal Inference Without Balance Checking. SSRN Electronic Journal. https://doi.org/10.2139/ssrn.1152391

Insler M (2014) The Health Consequences of Retirement. Journal of Human Resources 49:195233. https://doi.org/10.3368/jhr.49.1.195

Kim JE, Moen P (2002) Retirement transitions, gender, and psychological well-being: a lifecourse, ecological model. J Gerontol B Psychol Sci Soc Sci 57:P212-222

Lindeboom M (2006) Health and Work of Older Workers. Elgar Companion to Health Economics

Lindeboom M, Portrait F, van den Berg GJ (2002) An econometric analysis of the mental-health effects of major events in the life of older individuals. Health Econ 11:505-520. https://doi.org/10.1002/hec.746

Mazzonna F, Peracchi F (2017) Unhealthy Retirement? Journal of Human Resources 52:128151. https://doi.org/10.3368/jhr.52.1.0914-6627R1

Mazzonna F, Peracchi F (2009) Aging, Cognitive Abilities and Retirement in Europe. SSRN Electronic Journal. https://doi.org/10.2139/ssrn.1518440

Mazzonna F, Peracchi F (2012) Ageing, cognitive abilities and retirement. European Economic Review 56:691-710. https://doi.org/10.1016/j.euroecorev.2012.03.004

Messe P-J, Wolff F-C (2019) The short-term effects of retirement on health within couples: Evidence from France. Social Science \& Medicine 221:27-39. https://doi.org/10.1016/j.socscimed.2018.12.008 
Michie S, Williams S (2003) Reducing work related psychological ill health and sickness absence: a systematic literature review. Occup Environ Med 60:3-9

Neuman K (2008) Quit Your Job and Get Healthier? The Effect of Retirement on Health. Journal of Labor Research 29:177-201. https://doi.org/10.1007/s12122-007-9036-8

Rohwedder S, Willis RJ (2010) Mental Retirement. Journal of Economic Perspectives 24:119138. https://doi.org/10.1257/jep.24.1.119

Shai O (2018) Is retirement good for men's health? Evidence using a change in the retirement age in Israel. Journal of Health Economics 57:15-30. https://doi.org/10.1016/j.jhealeco.2017.10.008

Shmueli A (2003) Socio-economic and demographic variation in health and in its measures: the issue of reporting heterogeneity. Soc Sci Med 57:125-134 


\section{APPENDIX 1: REPRESENTATIVITY, RESPONSE RATE, AND ATTRITION IN THE SIP SURVEY}

The Santé et Itinéraire Professionnel (SIP) dataset surveyed individuals aged 20 to 74 in 2006 and 24 to 78 in 2010, all of whom were living in ordinary households in metropolitan France and are thus representative of this population. The global response rate for the survey was $76 \%$ (Bahu et al. 2012).

Attrition between the 2006 and 2010 waves amounts to $20 \%$, meaning that a little more than $80 \%$ of individuals surveyed in 2006 were also able to answer the survey in 2010. Such an attrition rate can induce the selection of a population with specific characteristics, even if the phenomenon is rather limited. Based on the sample's first wave demographic, socioeconomic, and health characteristics, there are no significant differences between respondents and nonrespondents to the 2010 survey. However, differences in the response rate to the 2010 survey exist according to declarations of perceived health status, activity limitations, major depressive episodes, and motion or sleep disorders. A sample that matches the characteristics of the general French population can be obtained through sample calibration, which was performed on the average of four Quarterly Employment surveys for the year 2006. The variables used were urban units, age groups, education, ethnicity, and the number of inhabitants in the dwelling (De Riccardis 2012). 


\section{APPENDIX 2: MAJOR DEPRESSIVE EPISODES (MDE) AND GENERALIZED ANXIETY DISORDERS (GAD)}

The MDE are identified in two stages. First, two questions are used as filters:

- Over the past two weeks, have you felt particularly sad or depressed mostly during the day and almost every day? Yes/No

- Over the past two weeks, have you been much less interested in most things or much less able to enjoy the things you used to enjoy most of the time? Yes/No

If one of these two filter questions receive a positive response, a third question is then asked in order to know the specific symptoms: "Over the past two weeks, when you felt depressed and/or uninterested in most things, did you experience any of the following situations? Check each "yes" answer. Several positive responses are possible.

- Your appetite changed significantly or you gained or lost weight without intending to (variation of $+/-5 \%$ in one month).

- You had trouble sleeping nearly every night (waking early or at night, sleeping too much).

- You talked or you moved more slowly than usual, or in contrast, felt agitated and had trouble staying in place, nearly every day.

- You felt tired almost all the time and without energy almost every day.

- You felt worthless or guilty almost every day.

- You had a hard time concentrating or making decisions almost every day.

- You had several dark thoughts such as wishing you were dead or thought about hurting yourself.

Using the responses, two algorithms are then implemented in accordance with the criteria of the Diagnostic and Statistical Manual (DSM-IV). An individual suffers from MDE if:

- One positive response is given to the two filter questions and four symptoms are listed.

- Two positive responses are given to the two filter questions and three symptoms are listed. 
GAD is identified using a similar system of filter questions.

Three questions are asked:

- Over the past six months, have you worried excessively or uncontrollably about minor everyday problems at work/school, at home, or about your relatives? Yes/No

If the answer is positive:

- Do you have such concerns almost every day? Yes/No

If this answer is positive:

- Is it difficult to control these concerns or do they prevent you from focusing on what you have to do? Yes/No

If the interviewee responds positively to the three filter questions, another question is asked in order to know the specific symptoms: "Over the last six months, when you felt particularly concerned, worried, or anxious, did you often:

- feel restless, tense, or on edge?

- have tense muscles?

- feel easily tired, weak, or exhausted?

- have trouble concentrating or your mind went blank?

- feel particularly irritable?

- have sleep problems (difficulty falling asleep, waking in the middle of the night, waking early, or sleeping too much)?

For a person to suffer from generalized anxiety disorder, he/she must respond positively to all three filter questions and to at least three of the subsequent six symptoms. This protocol is consistent with the one used by the DSM-IV.

\section{APPENDIX 3: EMPLOYMENT STATUS IN 2006 OF THE RETIRED AND NON-RETIRED POPULATIONS IN 2010}

\begin{tabular}{|c|c|c|c|c|c|c|}
\hline \multirow{2}{*}{ Retired in 2010} & \multicolumn{6}{|c|}{ Status towards employment in 2006} \\
\hline & Employed & Student & Unemployed & Retired & House-husb./wife & Other \\
\hline$\overline{\text { Yes }}$ & .218 & .000 & .037 & .689 & .031 & .024 \\
\hline No & .813 & .003 & .061 & .001 & .083 & .033 \\
\hline
\end{tabular}

Reading guide: $68.9 \%$ of the retired population in 2010 was already retired in 2006.

Field: Santé et Itinéraire Professionnel survey, individuals aged 45-74 in 2010. 


\section{APPENDIX 4: PROPORTION OF TOTAL HEALTH CONDITIONS, BY AGE}

\begin{tabular}{|c|c|c|c|c|c|}
\hline $\begin{array}{c}\text { Frequency } \\
\text { Percent }\end{array}$ & Poor SAH & $\begin{array}{l}\text { Chronic } \\
\text { disease }\end{array}$ & $\begin{array}{c}\text { Activity } \\
\text { limitation }\end{array}$ & Anxiety & Depression \\
\hline \multirow{2}{*}{45} & 51 & 73 & 30 & 18 & 17 \\
\hline & 0.79 & 1.13 & 0.46 & 0.28 & 0.26 \\
\hline \multirow{2}{*}{46} & 58 & 67 & 34 & 18 & 15 \\
\hline & 0.90 & 1.04 & 0.53 & 0.28 & 0.23 \\
\hline \multirow{2}{*}{47} & 61 & 69 & 38 & 16 & 11 \\
\hline & 0.94 & 1.07 & 0.59 & 0.25 & 0.17 \\
\hline \multirow{2}{*}{48} & 63 & 75 & 46 & 18 & 20 \\
\hline & 0.97 & 1.16 & 0.71 & 0.28 & 0.31 \\
\hline \multirow{2}{*}{49} & 63 & 79 & 41 & 17 & 15 \\
\hline & 0.97 & 1.22 & 0.63 & 0.26 & 0.23 \\
\hline \multirow{2}{*}{50} & 65 & 81 & 38 & 11 & 13 \\
\hline & 1.00 & 1.25 & 0.59 & 0.17 & 0.20 \\
\hline \multirow{2}{*}{51} & 90 & 89 & 55 & 19 & 20 \\
\hline & 1.39 & 1.38 & 0.85 & 0.29 & 0.31 \\
\hline \multirow{2}{*}{52} & 80 & 96 & 55 & 17 & 17 \\
\hline & 1.24 & 1.48 & 0.85 & 0.26 & 0.26 \\
\hline \multirow{2}{*}{53} & 79 & 80 & 45 & 19 & 22 \\
\hline & 1.22 & 1.24 & 0.70 & 0.29 & 0.34 \\
\hline \multirow{2}{*}{54} & 90 & 89 & 62 & 23 & 31 \\
\hline & 1.39 & 1.38 & 0.96 & 0.36 & 0.48 \\
\hline \multirow{2}{*}{55} & 80 & 93 & 50 & 20 & 19 \\
\hline & 1.24 & 1.44 & 0.77 & 0.31 & 0.29 \\
\hline \multirow{2}{*}{56} & 102 & 112 & 67 & 22 & 28 \\
\hline & 1.58 & 1.73 & 1.04 & 0.34 & 0.43 \\
\hline \multirow{2}{*}{57} & 107 & 130 & 87 & 25 & 33 \\
\hline & 1.65 & 2.01 & 1.34 & 0.39 & 0.51 \\
\hline \multirow{2}{*}{58} & 104 & 125 & 70 & 20 & 21 \\
\hline & 1.61 & 1.93 & 1.08 & 0.31 & 0.32 \\
\hline \multirow{2}{*}{59} & 92 & 97 & 66 & 23 & 23 \\
\hline & 1.42 & 1.50 & 1.02 & 0.36 & 0.36 \\
\hline \multirow{2}{*}{60} & 101 & 134 & 68 & 16 & 18 \\
\hline & 1.56 & 2.07 & 1.05 & 0.25 & 0.28 \\
\hline \multirow{2}{*}{61} & 91 & 118 & 65 & 14 & 19 \\
\hline & 1.41 & 1.82 & 1.00 & 0.22 & 0.29 \\
\hline \multirow{2}{*}{62} & 89 & 109 & 63 & 9 & 12 \\
\hline & 1.38 & 1.68 & 0.97 & 0.14 & 0.19 \\
\hline \multirow{2}{*}{63} & 115 & 152 & 77 & 15 & 24 \\
\hline & 1.78 & 2.35 & 1.19 & 0.23 & 0.37 \\
\hline \multirow{2}{*}{64} & 85 & 116 & 60 & 14 & 14 \\
\hline & 1.31 & 1.79 & 0.93 & 0.22 & 0.22 \\
\hline \multirow{2}{*}{65} & 84 & 101 & 54 & 8 & 5 \\
\hline & 1.30 & 1.56 & 0.83 & 0.12 & 0.08 \\
\hline 66 & 75 & 100 & 49 & 12 & 9 \\
\hline
\end{tabular}




\begin{tabular}{|c|c|c|c|c|c|}
\hline & 1.16 & 1.55 & 0.76 & 0.19 & 0.14 \\
\hline \multirow{2}{*}{67} & 60 & 92 & 34 & 3 & 5 \\
\hline & 0.93 & 1.42 & 0.53 & 0.05 & 0.08 \\
\hline \multirow{2}{*}{68} & 54 & 63 & 45 & 6 & 14 \\
\hline & 0.83 & 0.97 & 0.70 & 0.09 & 0.22 \\
\hline \multirow{2}{*}{69} & 58 & 92 & 41 & 11 & 11 \\
\hline & 0.90 & 1.42 & 0.63 & 0.17 & 0.17 \\
\hline \multirow{2}{*}{70} & 64 & 92 & 43 & 6 & 12 \\
\hline & 0.99 & 1.42 & 0.66 & 0.09 & 0.19 \\
\hline \multirow{2}{*}{71} & 79 & 83 & 57 & 8 & 11 \\
\hline & 1.22 & 1.28 & 0.88 & 0.12 & 0.17 \\
\hline \multirow{2}{*}{72} & 72 & 93 & 49 & 12 & 7 \\
\hline & 1.11 & 1.44 & 0.76 & 0.19 & 0.11 \\
\hline \multirow{2}{*}{73} & 75 & 85 & 49 & 3 & 12 \\
\hline & 1.16 & 1.31 & 0.76 & 0.05 & 0.19 \\
\hline \multirow{2}{*}{74} & 77 & 85 & 52 & 11 & 5 \\
\hline & 1.19 & 1.31 & 0.80 & 0.17 & 0.08 \\
\hline \multirow{2}{*}{ Total } & 2364 & 2870 & 1590 & 434 & 483 \\
\hline & 36.53 & 44.34 & 24.57 & 6.71 & 7.46 \\
\hline
\end{tabular}

Reading guide: $36.53 \%$ of the sample declared poor self-assessed health. In this specific population, $0.79 \%$ is aged 45 . Field: Santé et Itinéraire Professionnel survey, individuals aged 45-74 in 2010. 
APPENDIX 5: CONDITIONAL EXPOSURE LEVELS

\begin{tabular}{|c|c|c|c|c|c|c|c|c|c|c|}
\hline \multirow{2}{*}{$\begin{array}{c}\text { Education } \\
\text { Exposure }\end{array}$} & \multicolumn{2}{|c|}{ No education } & \multicolumn{2}{|c|}{ Primary/secondary } & \multicolumn{2}{|c|}{ Bachelor equivalent } & \multicolumn{2}{|c|}{ Post graduate } & \multicolumn{2}{|c|}{ Total } \\
\hline & Physical & Psychosocial & Physical & Psychosocial & Physical & Psychosocial & Physical & Psychosocial & Physical & Psychosocial \\
\hline Men & 15.99 & 8.05 & 12.53 & 6.84 & 4.88 & 6.74 & 2.35 & 5.34 & 10.14 & 6.7 \\
\hline Women & 9.94 & 6.98 & 7.31 & 6.35 & 3.46 & 5.13 & 2.94 & 4.76 & 6.05 & 5.88 \\
\hline Total & 12.99 & 7.52 & 9.84 & 6.58 & 4.05 & 5.8 & 2.69 & 5 & 7.94 & 6.26 \\
\hline
\end{tabular}

Note. In years.

Reading guide: The average exposure level to detrimental physical working conditions for a man with no education is 15.99 years.

Field: Santé et Itinéraire Professionnel survey, individuals aged 45-74 in 2010. 